\title{
Climate influence on Dinophysis spp. spatial and temporal distributions in Greek coastal water
}

\author{
Aristidis Vlamis ${ }^{1,2, *}$ \& Panagiota Katikou ${ }^{1}$ \\ ${ }^{1}$ National Reference Laboratory on Marine Biotoxins, Institute of Food Hygiene, Ministry of Rural Development and Food, \\ 3 A Limnou street, GR 54627, Thessaloniki, Greece \\ ${ }^{2}$ Present address: Myonias 38, 17342 Athens, Greece
}

Received 9 May 2013; Accepted 14 November 2013

\begin{abstract}
Presence of Dinophysis spp., the main phytoplankton genus responsible for the occurrence of lipophilic biotoxins of the okadaic acid group (Diarrhetic Shellfish Poisoning; DSP) in Greek mussels, was recorded in the period 2003-2008 in five major mussel culture areas of Greece. Dinophysis spp. abundances were simultaneously studied with climatological parameters (air temperature, rainfall, wind direction and velocity) and the occurrence of DSP toxic episodes in mussels. Dinophysis spp. blooms occurred with a seasonal periodicity. Highest cell abundances of the bloom appeared steadily between late winter and spring, whereas occurrence of DSP toxicity in mussels followed a similar time pattern, with mouse bioassay-positive samples ranging between $10.2-28.1 \%$ of the total samples analysed. Maximum mean Dinophysis spp. counts coincided with air temperatures in the range of $10-20^{\circ} \mathrm{C}$; abundances higher than 1,000 cells $\mathrm{L}^{-1}$ were more frequently recorded at air temperatures in the range of $4-20^{\circ} \mathrm{C}$ in combination with low rainfall and low velocity winds ( $<$ Beaufort scale 4$)$, blowing from the north $(\mathrm{NW}, \mathrm{N}$ and NE) and south (SE and S). To our knowledge, this is the first report to correlate the occurrences and abundances of potentially toxic Dinophysis spp. and climatological data for the majority of the shellfish production areas studied. Such observations may contribute to the clarification of the occurrence patterns of DSP toxic episodes, hence bettering the economical management of mussel production.
\end{abstract}

Key words: air temperature, Diarrhetic Shellfish Poisoning, Dinophysis spp., rainfall, wind

\section{Introduction}

Lipophilic biotoxins are toxic compounds mainly produced by species of the genera Dinophysis, Prorocentrum, Protoceratium, Gonyaulax, Lingulodinium, Protoperidinium and Azadinium (Daranas et al. 2001, Paz et al. 2004, Tillmann et al. 2009). The main toxin groups included are okadaic acid (OA) and dinophysistoxins (DTX), pectenotoxins (PTX), yessotoxins (YTX) and azaspiracids (AZA). Members of the OA group (OA, DTXs and PTXs), considered as one of the most important, are commonly referred to as Diarrhetic Shellfish Poisoning (DSP) toxins. The presence of DSP toxins is primarily connected to blooms of the toxic genus Dinophysis and to a lesser extent to the genus Prorocentrum. Species belonging to the genus Dinophysis have a wide distribution and are encountered in

\footnotetext{
*Corresponding author: Aristidis Vlamis; E-mail, biotoxin@otenet.gr
}

tropical, subtropical and temperate seas (Hallegraeff \& Lucas 1988, van den Hoek et al. 1995). Investigation of Dinophysis spp. biology has progressed considerably in recent decades, due to its increasingly recorded presence in numerous coastal areas worldwide and the accompanying shellfish toxicity (Hallegraeff 1993, Zingone \& Enevoldsen 2000).

Geographical distribution and seasonal periodicity of the cosmopolitan genus Dinophysis varies even between adjacent areas. Potential factors contributing to these differences include, among others, environmental conditions, water movement and geomorphology of the area. Seasonal periodicity of Dinophysis spp. presence during the year is common in Thermaikos Gulf, Greece (Koukaras \& Nikolaidis 2004, Nikolaidis et al. 2005), in other European countries (Bernardi Aubry et al. 2000, Vale \& Sampayo 2003, France \& Mozetič 2006, Ninčević-Gladan et al. 2008) and worldwide (Koike et al. 2000, Morton et al. 
2009, Swanson et al. 2010). These seasonal patterns seem to be partly related to regional parameters influencing Dinophysis blooms, such as the movement of water masses due to different densities or winds (Lindahl \& Andersson 1996, Moita \& da Silva 2001), temperature (Reguera et al. 1995, Hoshiai et al. 1996, Dahl \& Johannessen 2001, Godhe et al. 2002) and rainfall (Vale \& Sampayo 2003). Changes in these parameters may subsequently influence nutrient availability and/or water column stability, and can therefore greatly affect Dinophysis spp. growth patterns (Estrada \& Berdalet 1997, Vale \& Sampayo 2003). Moreover, other factors such as latitude, as well as water column and food web dynamics, have influences on geographical distributions (Reguera et al. 2012).

According to available data of the Greek National Reference Laboratory for Marine Biotoxins (NRLMB), marine biotoxins' episodes in Greece during the period 2000-2008 almost exclusively involved lipophilic toxins of the DSP group (Mouratidou et al. 2004, Prassopoulou et al. 2009, Louppis et al. 2010). These toxins occur in shellfish production areas almost steadily on a regular yearly basis; duration and time of toxicity occurrence, however, do not always coincide, even between neighboring areas. The possibility of reducing, or even avoiding, time coincidence between periods of lipophilic toxin-induced regulatory closures and shellfish commercialization in shellfish production areas, may be a significant contribution towards a more efficient time management of regional shellfish production. This could be partly facilitated by further clarification of Dinophysis spp. presence at seasonal and geographical levels in Greek coastal waters where mussel cultures are located, taking into account the potential influence of respective climatological parameters. The purpose of this study was therefore to investigate temporal and spatial distributions of potentially toxic Dinophysis spp. in Greek coastal waters, as well as the relationship between algal presence and climatological parameters (air temperature, rainfall, wind direction and velocity), using monitoring data from the five major Greek mussel culture areas, representing ca. $95 \%$ of Greek mussel production during the period 2003-2008. It should be pointed out that the actual target of the present study is the establishment of a practically applicable approach, and not the construction of a mathematical method. The approach, which would be easily perceivable and useful to relevant interested parties (e.g. shellfish farmers, official control personnel) is to be based on the clarification of the periodicity and effect of climatological data on the occurrence of DSP toxic episodes. In order to serve this purpose, the study design was based only on data freely accessible to the public, i.e. climatological data (air temperature, rainfall, wind direction and velocity) and official regulatory monitoring data on Dinophysis spp. counts and DSP toxins' presence.

\section{Materials and Methods}

\section{Study area and sampling stations}

All laboratory analysis data originated from the five major mussel culture coastal areas: Saronikos Gulf, Thermaikos Gulf, Maliakos Gulf, Gulf of Kavala and Amvrakikos Gulf (Fig. 1). Regulatory implementation of monitoring for these coastal areas falls within the jurisdiction of seven prefectural veterinary services: three for Thermaikos Gulf (Thessaloniki, Imathia and Pieria), one for Saronikos Gulf (Dytiki Attiki/Megara), one for Maliakos Gulf (Fthiotida), one for Gulf of Kavala (Kavala) and one for Amvrakikos Gulf (Preveza). The exact location of individual sampling stations for each prefecture, expressed by geographical coordinates (latitude and longitude), is provided in Table 1.

\section{Sampling and laboratory analysis}

Samples and respective data on Dinophysis spp. counts and presence of DSP toxins were derived from the Greek "National Program for Monitoring of Bivalve Molluscs' Production Areas for the presence of Marine Biotoxins" during the years 2003-2008; coordination was provided by the Ministry of Rural Development and Food (MRDF,

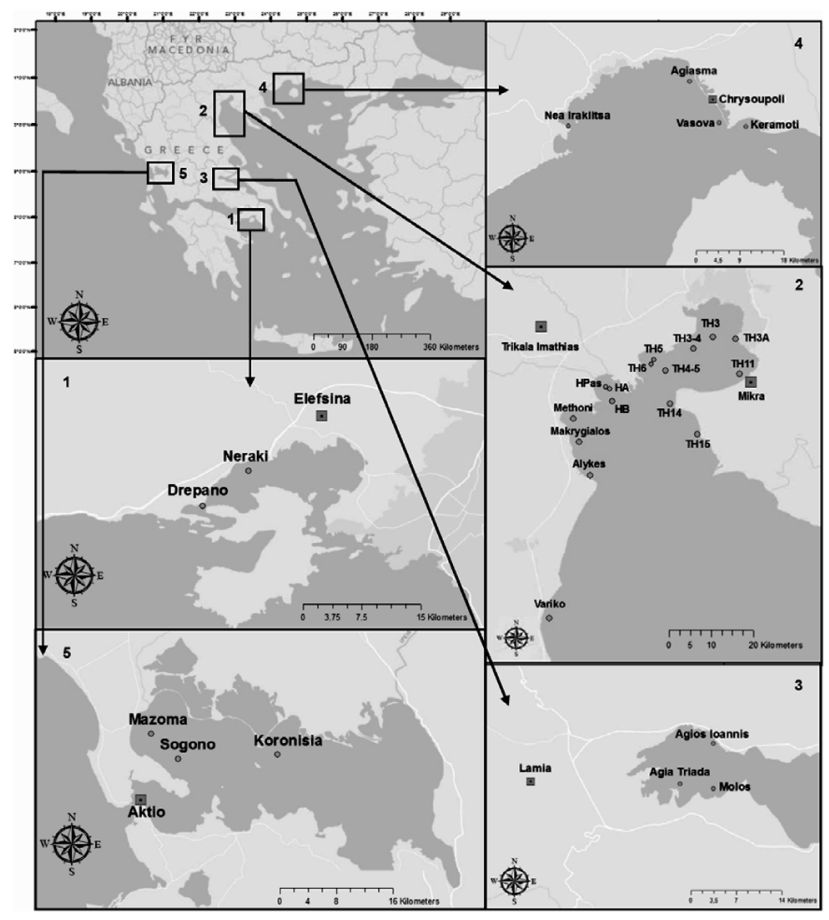

Fig. 1. Maps showing locations of sampling stations in (1) Saronikos Gulf, (2) Thermaikos Gulf, (3) Maliakos Gulf, (4) Gulf of Kavala and (5) Amvrakikos Gulf. Round marks $(\bigcirc)$ depict the location of individual sampling stations. Square marks $(\square)$ depict the location of the nearest meteorological station providing climatological data for the study. See Tables 1 and 2 for full geographic coordinates. 
Table 1. Locations of sampling stations for each coastal area included in the study, expressed by geographical coordinates (longitude and latitude).

\begin{tabular}{|c|c|c|c|c|c|c|c|}
\hline Coastal area & Prefecture & $\begin{array}{c}\text { Declared annual } \\
\text { cultured mussel } \\
\text { production (tonnes) }\end{array}$ & Sampling station & $\begin{array}{l}\text { Latitude } \\
\text { (N) }\end{array}$ & $\begin{array}{l}\text { Longitude } \\
\text { (E) }\end{array}$ & $\begin{array}{l}\text { Water column depth } \\
\qquad(\mathrm{m})\end{array}$ & $\begin{array}{c}\text { Mussel } \\
\text { sampling } \\
\text { depth (m) }\end{array}$ \\
\hline \multirow[t]{17}{*}{$\begin{array}{l}\text { Thermaikos } \\
\text { Gulf }\end{array}$} & \multirow[t]{10}{*}{ Thessaloniki } & \multirow[t]{10}{*}{4,000} & Kymina (HA) & $40^{\circ} 30^{\prime} 22^{\prime \prime}$ & $22^{\circ} 41^{\prime} 06^{\prime \prime}$ & $\max 15$ & $4-8$ \\
\hline & & & Peraia (TH11) & $40^{\circ} 31^{\prime} 40^{\prime \prime}$ & $22^{\circ} 56^{\prime} 33^{\prime \prime}$ & $\max 15$ & $\mathrm{n} / \mathrm{a}^{1}$ \\
\hline & & & Aggelohori (TH14) & $40^{\circ} 28^{\prime} 59^{\prime \prime}$ & $22^{\circ} 48^{\prime} 20^{\prime \prime}$ & $\max 15$ & $4-8$ \\
\hline & & & Epanomi (TH15) & $40^{\circ} 26^{\prime} 15^{\prime \prime}$ & $22^{\circ} 51^{\prime} 33^{\prime \prime}$ & $\max 15$ & $4-8$ \\
\hline & & & $\begin{array}{l}\text { Fanos Paliomanas } \\
(\mathrm{TH} 3)\end{array}$ & $40^{\circ} 35^{\prime} 01^{\prime \prime}$ & $22^{\circ} 53^{\prime} 25^{\prime \prime}$ & $\max 20$ & $\mathrm{n} / \mathrm{a}$ \\
\hline & & & Paliomana (TH3-4) & $40^{\circ} 33^{\prime} 59^{\prime \prime}$ & $22^{\circ} 51^{\prime} 06^{\prime \prime}$ & $\max 20$ & $\mathrm{n} / \mathrm{a}$ \\
\hline & & & Naziki (TH4-5) & $40^{\circ} 32^{\prime} 00^{\prime \prime}$ & $22^{\circ} 47^{\prime} 48^{\prime \prime}$ & $\begin{array}{l}\max 6 \text { (pole cultivation) } \\
\max 20 \text { (long-line) }\end{array}$ & $\begin{array}{l}2-4 \\
4-8\end{array}$ \\
\hline & & & Lefkoudi (TH5) & $40^{\circ} 33^{\prime} 00^{\prime \prime}$ & $22^{\circ} 46^{\prime} 24^{\prime \prime}$ & $\begin{array}{l}\max 6 \text { (pole cultivation) } \\
\max 20 \text { (long-line) }\end{array}$ & $\begin{array}{l}2-4 \\
4-8\end{array}$ \\
\hline & & & Kavoura (TH6) & $40^{\circ} 32^{\prime} 35^{\prime \prime}$ & $22^{\circ} 46^{\prime} 02^{\prime \prime}$ & $\begin{array}{l}\max 6 \text { (pole cultivation) } \\
\max 20 \text { (long-line) }\end{array}$ & $\begin{array}{l}2-4 \\
4-8\end{array}$ \\
\hline & & & Karabournaki (TH3A) & $40^{\circ} 34^{\prime} 51^{\prime \prime}$ & $22^{\circ} 6^{\prime} 06^{\prime \prime}$ & $\max 15$ & $\mathrm{n} / \mathrm{a}$ \\
\hline & \multirow[t]{4}{*}{ Pieria } & \multirow[t]{4}{*}{11,500} & Alykes (P1) & $40^{\circ} 22^{\prime} 30^{\prime \prime}$ & $22^{\circ} 38^{\prime} 50^{\prime \prime}$ & $6-15$ & $3-4$ \\
\hline & & & $\begin{array}{l}\text { Makrygialos } \\
\text { (P2A and P2B) }\end{array}$ & $40^{\circ} 25^{\prime} 30^{\prime \prime}$ & $22^{\circ} 37^{\prime} 30^{\prime \prime}$ & $6-15$ & $3-4$ \\
\hline & & & $\begin{array}{l}\text { Methoni } \\
\text { (P3A and P3B) }\end{array}$ & $40^{\circ} 27^{\prime} 37^{\prime \prime}$ & $22^{\circ} 36^{\prime} 48^{\prime \prime}$ & $6-15$ & $3-4$ \\
\hline & & & Variko & $40^{\circ} 09^{\prime} 31^{\prime \prime}$ & $22^{\circ} 33^{\prime} 54^{\prime \prime}$ & $6-15$ & $3-4$ \\
\hline & \multirow[t]{3}{*}{ Imathia } & \multirow[t]{3}{*}{5,000} & HA & $40^{\circ} 30^{\prime} 22^{\prime \prime}$ & $22^{\circ} 41^{\prime} 06^{\prime \prime}$ & $\max 20$ & $2-5$ \\
\hline & & & $\mathrm{HB}$ & $40^{\circ} 29^{\prime} 15^{\prime \prime}$ & $22^{\circ} 41^{\prime} 27^{\prime \prime}$ & $\max 20$ & $2-5$ \\
\hline & & & HPas & $40^{\circ} 30^{\prime} 30^{\prime \prime}$ & $22^{\circ} 40^{\prime} 40^{\prime \prime}$ & $\max 6$ & $2-4$ \\
\hline \multirow{2}{*}{$\begin{array}{l}\text { Saronikos } \\
\text { Gulf }^{1}\end{array}$} & Dytiki Attiki/ & \multirow[t]{2}{*}{300} & Neraki & $38^{\circ} 0^{\prime} 59.33^{\prime \prime}$ & $23^{\circ} 27^{\prime} 55.16^{\prime \prime}$ & $\max 20$ & $2-5$ \\
\hline & Megara & & Drepano & $37^{\circ} 59^{\prime} 3.72^{\prime \prime}$ & $23^{\circ} 24^{\prime} 44.55^{\prime \prime}$ & $\max 8$ & $2-5$ \\
\hline \multirow{3}{*}{$\begin{array}{l}\text { Maliakos } \\
\text { Gulf }\end{array}$} & \multirow[t]{3}{*}{ Fthiotida } & \multirow[t]{3}{*}{700} & Agios Ioannis Stylidas & $38^{\circ} 53^{\prime} 26^{\prime \prime}$ & $22^{\circ} 39^{\prime} 06^{\prime \prime}$ & $6-10$ & $2-4$ \\
\hline & & & Agia Triada & $38^{\circ} 50^{\prime} 49^{\prime \prime}$ & $22^{\circ} 36^{\prime} 21^{\prime \prime}$ & $6-10$ & $2-4$ \\
\hline & & & Molos & $38^{\circ} 50^{\prime} 30^{\prime \prime}$ & $22^{\circ} 39^{\prime} 05^{\prime \prime}$ & $6-10$ & $2-4$ \\
\hline \multirow{4}{*}{$\begin{array}{l}\text { Gulf of } \\
\text { Kavala }^{2}\end{array}$} & \multirow[t]{4}{*}{ Kavala } & \multirow[t]{4}{*}{3,000} & Keramoti & $40^{\circ} 51^{\prime} 42.11^{\prime \prime}$ & $24^{\circ} 39^{\prime} 37.20^{\prime \prime}$ & $\max 15$ & $2-5$ \\
\hline & & & Nea Iraklitsa & $40^{\circ} 51^{\prime} 42.80^{\prime \prime}$ & $24^{\circ} 20^{\prime} 0.10^{\prime \prime}$ & $\max 25$ & $2-5$ \\
\hline & & & Vasova & $40^{\circ} 52^{\prime} 01.15^{\prime \prime}$ & $24^{\circ} 36^{\prime} 39.85^{\prime \prime}$ & $\max 17$ & $2-5$ \\
\hline & & & Agiasma & $40^{\circ} 55^{\prime} 30.14^{\prime \prime}$ & $24^{\circ} 33^{\prime} 23.38^{\prime \prime}$ & $\max 21$ & $2-5$ \\
\hline \multirow{3}{*}{$\begin{array}{l}\text { Amvrakikos } \\
\text { Gulf }^{1}\end{array}$} & \multirow[t]{3}{*}{ Preveza } & \multirow[t]{3}{*}{30} & Koronisia & $38^{\circ} 59^{\prime} 52.08^{\prime \prime}$ & $20^{\circ} 56^{\prime} 33.29^{\prime \prime}$ & $\max 28$ & $1-3$ \\
\hline & & & Mazoma & $39^{\circ} 1^{\prime} 5.51^{\prime \prime}$ & $20^{\circ} 46^{\prime} 52.60^{\prime \prime}$ & $\max 20$ & $1-3$ \\
\hline & & & Sogono & $38^{\circ} 59^{\prime} 34.93^{\prime \prime}$ & $20^{\circ} 48^{\prime} 57.70^{\prime \prime}$ & $\max 20$ & $1-3$ \\
\hline
\end{tabular}

${ }^{1} \mathrm{n} / \mathrm{a}$ : sampling point only for microalgal monitoring and for harvested (not cultured) shellfish species.

${ }^{2}$ Sampling stations in these coastal areas are defined by four points; values provided correspond to the midpoint.

2002). The monitoring program requires weekly sampling during the whole year as the minimum frequency for regulatory controls, turning to twice-weekly whenever abundances of toxic and/or potentially toxic phytoplankton exceeded the nationally established surveillance limits. With regard to abundances of microalgal cells considered as po- tentially toxic for the production of lipophilic toxins, including Dinophysis spp., the established national threshold limits designate the regulatory status of shellfish production areas as: open $\left(1-199\right.$ cells $\left.\mathrm{L}^{-1}\right)$, under surveillance (200-999 cells $\left.\mathrm{L}^{-1}\right)$ and closed $\left(\geq 1,000\right.$ cells $\left.\mathrm{L}^{-1}\right)$. A closed regulatory status with regard to DSP toxicity in mussels 
was designated in a production area by toxicity detection in mouse bioassays (MBA positive sample), whereas three consecutive negative samples in at least 8 days were required to re-open the production area. According to these requirements, each of the two parameters separately (increased cell abundances and MBA toxicity) or both in combination can be the cause of a regulatory closure.

All sampling was conducted by the relevant Prefectural Veterinary and/or Fisheries authorities. Cell counts of toxic and/or potentially toxic phytoplankton in seawater, specifically of the genus Dinophysis, were conducted by the Laboratory Unit of Toxic Marine Microalgae (LUTMM), Department of Biology, Aristotle University of Thessaloniki, and all data were forwarded to the NRLMB by the prefectural authorities, as indicated in the monitoring program. Analyses for presence or absence of DSP toxicity in mussel samples were conducted by the NRLMB, Institute of Food Hygiene of Thessaloniki, MRDF. At each station, integrated seawater samples (aliquots of $500 \mathrm{~mL}$ ) for phytoplankton identification were collected on a weekly basis from the whole water column (as required by the EU Regulation 854/2004) using a dividable PVC tube-sampler equal to the depth of each station (see Table 1). Seawater samples were immediately preserved with Lugol's solution. At the same time shellfish (mussels: Mytilus galloprovincialis Lamarck, 1819) samples were also collected. Both seawater and shellfish samples were transferred to the relevant laboratories within $24 \mathrm{~h}$.

Sea water samples were analyzed for the presence of toxic and/or potentially toxic phytoplankton by Utermöhl's sedimentation method (Utermöhl 1958), using inverted microscopy for identification and enumeration of the phytoplankton cells. Briefly, after homogenizing the samples, sub-samples were allowed to settle in $25 \mathrm{~mL}$ sedimentation chambers. Dinophysis spp. cells were counted under an inverted microscope at 100x and 400x magnifications so that the detection limit was 40 cell $\mathrm{L}^{-1}$. The quantitative analysis for low abundances was performed by counting the detected cells on the entire surface of the settling chamber, whereas in the case of high level abundances a number of randomly selected fields were counted until reaching a count of at least 400 cells.

Mussel hepatopancreas (HP) samples were tested for the presence of lipophilic toxins by the mouse bioassay (MBA) protocol of Yasumoto et al. (1978). Briefly, a $20 \mathrm{~g}$ portion of HP was extracted thrice with $50 \mathrm{~mL}$ acetone each time and filtered through a cellulose filter. The combined toxin extract was evaporated to dryness and resuspended in $1 \%$ Tween-60 to a final volume of $4 \mathrm{~mL}(5 \mathrm{~g} \mathrm{HP} / \mathrm{mL})$. Each one of three mice (Albino Swiss, 18-20 g body weight) was injected intraperitoneally with $1 \mathrm{~mL}$ of this solution. The criterion of toxicity established by the EU Regulation 2074/2005 (2005) was employed, which is the death of two out of three mice within $24 \mathrm{~h}$ of injection with an extract equivalent to $5 \mathrm{~g}$ of $\mathrm{HP}$ or $25 \mathrm{~g}$ of whole flesh tissue. This constitutes a positive result for the presence of the lipo- philic toxins mentioned in the above Regulation, including OA, DTX-1, -2 and -3 . The mice were allowed laboratory feed and water ad libitum throughout the observation period. All animal manipulations were performed in accordance with the EU Directive 86/609/EEC (1986) and the EU Recommendation 2007/526/EC (2007), under official license from the Prefectural Veterinary Service of Thessaloniki, Greece.

\section{Climatological data}

Climatological data (air temperature, wind direction and velocity, rainfall) were provided by the Hellenic National Meteorological Service (HNMS) from selected meteorological stations located as close as possible to the areas of interest (Table 2 and Fig. 1). The use of air temperature data in place of relevant seawater temperature measurements in the present study can be justified due to the rather limited maximum depth (up to $28 \mathrm{~m}$ ) of the sampling sites (Table 1). According to Kara et al. (2009), the difference between sea surface temperature and water temperature at depths of at least $34 \mathrm{~m}$ in the Aegean Sea presents a maximum variation of $0.5^{\circ} \mathrm{C}$, which indicates a well mixed water mass. On the other hand, Poulos et al. (1997) studied the relationship of air temperature versus sea surface temperature in the Aegean Sea and reported that the main factors affecting sea surface temperatures (SST) are the seasonal atmospheric conditions, which are reflected in the air temperature (AT). Theoharatos \& Tselepidaki (1990) have established that the cross correlation coefficient between SST and AT, for 15 stations from the Aegean Sea, is $r^{2}>0.80$ (significant at the $95 \%$ level). Monthly variations in SST and AT showed that, on an annual basis, the sea temperature appeared to lag in relation to that of the overlying airmass by the order of a month. Finally, a principal component analysis carried out by Vlahakis \& Pollatou (1993) showed that SST changes, related to AT fluctuations, occur almost simultaneously throughout the Aegean Sea.

Climatological data obtained by the HNMS usually required initial transformation in order to be in the appropriate form for a combined statistical analysis in conjunction

Table 2. Details and locations of the Hellenic National Meteorological Service meteorological stations included in the study.

\begin{tabular}{clrll}
\hline & & \multicolumn{3}{c}{ Station location } \\
\cline { 3 - 5 } $\begin{array}{c}\text { HNMS } \\
\text { Code }\end{array}$ & Station & $\begin{array}{c}\text { Altitude } \\
(\mathrm{m})\end{array}$ & $\begin{array}{c}\text { Latitude } \\
(\mathrm{N})\end{array}$ & $\begin{array}{c}\text { Longitude } \\
(\mathrm{E})\end{array}$ \\
\hline & & & & \\
\hline 619 & Trikala Imathias & 0.8 & $40^{\circ} 6^{\prime} 0.00^{\prime \prime}$ & $22^{\circ} 33^{\prime} 0.00^{\prime \prime}$ \\
622 & Mikra & 4.8 & $40^{\circ} 31^{\prime} 0.00^{\prime \prime}$ & $22^{\circ} 57^{\prime} 60.00^{\prime \prime}$ \\
624 & Chrysoupoli & 5.4 & $40^{\circ} 53^{\prime} 60.00^{\prime \prime}$ & $24^{\circ} 36^{\prime} 0.00^{\prime \prime}$ \\
643 & Aktio & 4.0 & $38^{\circ} 58^{\prime} 0.00^{\prime \prime}$ & $20^{\circ} 46^{\prime} 0.00^{\prime \prime}$ \\
675 & Lamia & 17.4 & $38^{\circ} 51^{\prime} 0.00^{\prime \prime}$ & $22^{\circ} 23^{\prime} 60.00^{\prime \prime}$ \\
718 & Elefsina & 31.0 & $38^{\circ} 4^{\prime} 0.00^{\prime \prime}$ & $23^{\circ} 33^{\prime} 0.00^{\prime \prime}$
\end{tabular}


with the laboratory data. For air temperature and rainfall data, originally consisting of individual recordings at different times of day, daily averaging was considered necessary to obtain a single value for each day and meteorological station. Wind velocity data required transformation from knots to the Beaufort scale. For wind direction data, expressed initially in degrees in the range of $0-360^{\circ}$ with no daily averaging possible, calculation of the prevailing wind direction on a daily basis was conducted according to the method described by the US Environmental Protection Agency (2000), taking into account both wind speed raw data and wind direction "azimuth". Intensity of rainfall was classified according to the American Meteorological Society (2012) definitions as: a) "light" the rate of fall varying between a trace and $2.5 \mathrm{~mm}$ per hour; b) "moderate" from 2.6 to $7.6 \mathrm{~mm}$ per hour and c) "heavy" over $7.6 \mathrm{~mm}$ per hour.

\section{Data processing and statistical analysis}

Some initial data categorization and transformation were required in order to facilitate graphical representation and statistical analysis by the software package. Despite the fact that sampling intervals were weekly, sampling dates for each year were divided into 24 fortnights, encoded by an alphanumeric code indicating the specific month and fortnight, e.g.: JAN/1= January-first fortnight, $\mathrm{JUN} / 2=\mathrm{June}-$ second fortnight and $\mathrm{DEC} / 2=$ Decembersecond fortnight, in order to facilitate the statistical evaluation.

Statistical analysis and graphic representation was conducted using Minitab ${ }^{\circledR}$ version 15 (Minitab Inc., Coventry, UK). Normality of data was evaluated by the KolmogorovSmirnov test, and homogeneity of variance was examined using residual graphs and the Levene test. In cases where statistical normality and/or homogeneity was lacking, data transformation was applied, e.g. Dinophysis spp. counts were transformed onto a logarithmic scale $[\log (\mathrm{x})+1]$ to obtain a continuous variable with no zero values. In all cases, statistical transformation produced normality and homogeneity of variance (Petridis 2000). Statistical methods employed included: (a) one-way Analysis of Variance (ANOVA), with the mean confidence interval set at $95 \%$ and calculated by the ANOVA error and significance of difference of means tested by the Fisher's least significant difference (LSD) test and (b) Principal Components Analysis (PCA). PCA was conducted on the whole dataset to investigate the contribution of all studied parameters (fortnight of the year, wind direction, air temperature, rainfall, logarithmic Dinophysis spp. counts and wind velocity) to the occurrence of DSP toxic episodes in the total study area. Selection of principal components (PC) was based on a combination of criteria: (a) the Kaiser rule according to which selected PCs have to bear an Eigenvalue larger or equal/near to one (eigenvaluegreaterthanone rule) and (b) explained variance of at least $70 \%$, whereas loading factors for explaining contributions within a PC were taken into account when their absolute value was greater than 0.5 (Joliffe 2002). Finally, graphical representation of data involved the use of interval plots, dispersion charts, contour plots and a PCA loading plot, showing only the first two PCs due to restrictions of the Minitab software.

\section{Results}

\section{Geographical distribution of Dinophysis spp.}

Statistical evaluation of Dinophysis spp. abundances (total number of analyzed samples, $\mathrm{n}=6,686$ ) over the whole study area across the total six-year monitoring period indicated that mean Dinophysis spp. abundances (cells $\left.\mathrm{L}^{-1}\right)$ were comparable $(p>0.05)$ for some areas, while statistically significant differences $(p \leq 0.05, \quad F=75.72$, $F_{\text {crit }}=.01$ ) were observed between certain others (Fig. 2). Based on statistical significance testing results, prefectures can be divided into three groups (Fig. 2; depicted within the same ellipse) with regard to their mean Dinophysis spp. counts. The first group contains only the area of Kavala (Gulf of Kavala), with very low Dinophysis spp. cell abundances, which could thus be characterized as the prefecture with the lowest incidence of DSP toxic episodes (Vlamis et al. 2010). This is strongly supported by the fact that during the whole study period, with a total of 564 seawater samples analyzed, Dinophysis spp. abundances in Kavala reached the regulatory level of 1,000 cells $\mathrm{L}^{-1}$ only once, exceeded the surveillance level of 200 cells $\mathrm{L}^{-1}$ in only eight instances, and the presence of DSP toxins in mussels resulted in only three closures with a maximum duration of 17 days. The second group consists of the prefectures of Dytiki Attiki (Saronikos Gulf), Imathia and Pieria (Thermaikos Gulf) and Fthiotida (Maliakos Gulf), in which the mean Dinophysis spp. cell abundances ranged within similar $(p>0.05)$ levels. Finally, the prefectures of Thessaloniki

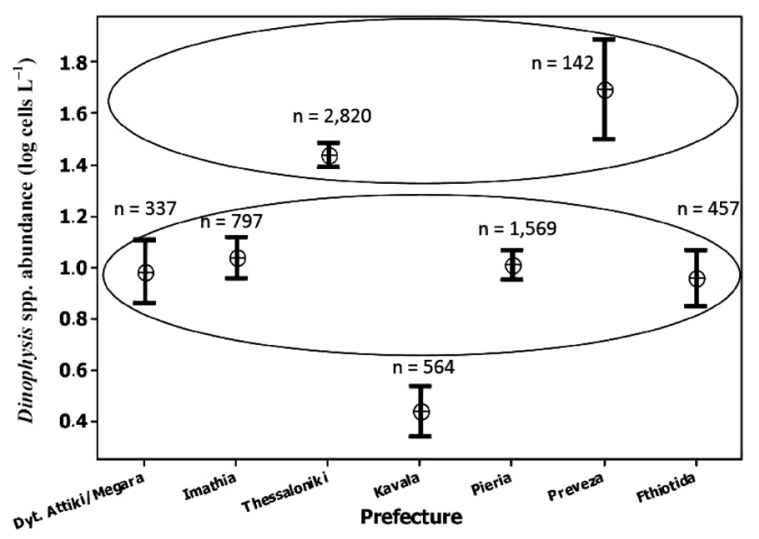

Fig. 2. Dinophysis spp. abundance during the period 20032008 by Prefecture $(\oplus$ : mean value; $\perp$ : $95 \%$ confidence interval of the mean). Means within the same ellipse are not significantly different $(p>0.05)$. Number of averaged samples $(n)$ per area is presented above each mean value. 
(Thermaikos Gulf) and Preveza (Amvrakikos Gulf) comprise the third group with the highest mean values of Dinophysis spp. abundances. It should be noted that the mean confidence interval range for Thessaloniki prefecture was more limited than that of Preveza, due to the fact that the mean value for the former was derived by the analysis of a significantly larger amount of raw data (see Fig. 2), as in the latter case samplings were conducted much less frequently or even sporadically in certain cases.

No statistically significant differences $(p>0.05)$ were observed between Dinophysis spp. cell abundances at individual sampling stations located in the same area/prefecture in the cases of Saronikos Gulf (Dytiki Attiki: 2 sampling stations; $p>0.05, F=2.92, F_{\text {crit }}=3.87$ ), Gulf of Kavala (Kavala: 4 sampling stations; $p>0.05, F=0.57$, $F_{\text {crit }}=2.62$ ), Maliakos Gulf (Fthiotida: 3 sampling stations; $p>0.05, F=0.08, F_{\text {crit }}=3.02$ ) and/or Amvrakikos Gulf (Preveza, 3 sampling stations; $p>0.05, F=0.01, F_{\text {crit }}=3.06$ ) (data not shown). However, this was not the case with the results of the mean Dinophysis spp. abundances in Thermaikos Gulf. Significant differences $(p \leq 0.05, F=5.68$, $F_{\text {crit }}=1.88$ ) were noted between mean counts at certain sampling stations located in the northwestern Thermaikos Gulf and in Thessaloniki Bay (inner sea area of Thermaikos Gulf), within the jurisdiction of Thessaloniki prefecture (Fig. 3). Specifically, sampling stations located outside the boundaries of Thessaloniki Bay, in central Thermaikos Gulf, had significantly lower Dinophysis spp. cell abundances compared to all other stations, except for the sampling station TH14, located at the boundaries of Thessaloniki Bay. Counts at the latter station significantly differed only from those of stations located in the inner part of Thessaloniki Bay, whereas no significant differences $(p>0.05)$ were found between Dinophysis spp. abundances at any of the sampling stations located inside Thessaloniki Bay.

During the whole study period the maximum Dinophy-

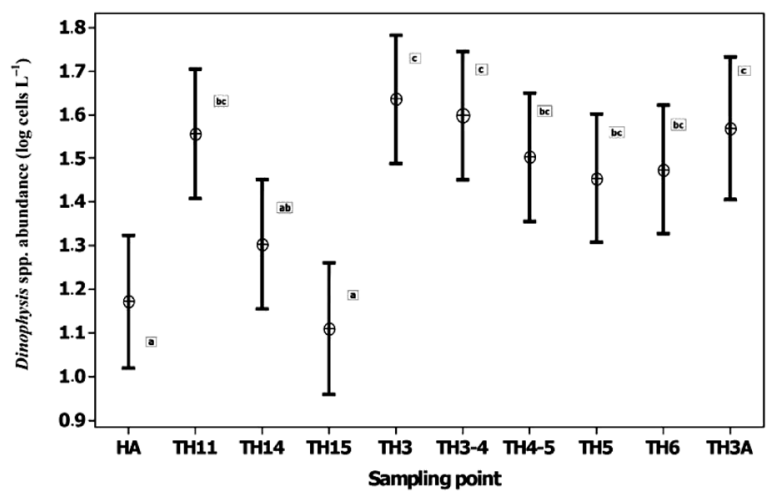

Fig. 3. Dinophysis spp. abundance at the sampling stations in Thessaloniki prefecture during the period 2003-2008 ( $\oplus$ : mean value; $\perp: 95 \%$ confidence interval of the mean). Mean values with the same letter $(a, b, c)$ on the right of the bars are not significantly different from each other. sis spp. cell abundances were recorded in the mussel production areas of western Thermaikos Gulf (Thessaloniki, sampling stations TH4-5: 87,280 cells L $^{-1}$ and TH6: 86,680 cells L ${ }^{-1}$, both in February 2008) and Saronikos Gulf (Dytiki Attiki, sampling station Neraki: 76,280 cells $\mathrm{L}^{-1}$ in December 2006), in full agreement with the longest regulatory closure periods recorded for the same sampling stations due to presence of DSP toxins in mussels, i.e. 153 days (December 2007-May 2008), 160 days (December 2007-June 2008) and 139 days (December 2006-April 2007), respectively. The dominant Dinophysis species in these cases was Dinophysis ef. acuminata (LUTMM, personal communication), later redefined by Papaefthimiou et al. (2010) as Dinophysis. cf. ovum.

\section{Temporal variation of Dinophysis spp. abundances}

Available data during the monitoring period 2003-2008 demonstrate an evident increase of Dinophysis spp. mean abundances during the year 2004 followed by 2006, with these maximum values being statistically significantly different from those of the remaining years, as well as between each of those years $\left(p \leq 0.05, F=25.78, F_{\text {crit }}=2.22\right)$. On the other hand, mean Dinophysis spp. cell abundances for the year 2003 were considerably lower $(p \leq 0.05)$ compared to the other five years included in the study (Fig. 4a). These findings are mostly in disagreement with the intensity of the relevant DSP toxic episodes in mussels, as represented by the number and percentage rate of DSP positive samples per year (Fig. 4b). Except for the fact that both maximum values occurred in 2004 , all other studied years fail to show a clear correlation between cell abundances and frequency of DSP positive samples, indicating that there are other factors determining the intensity of the episodes.

Yearly trends for individual areas followed more or less the patterns outlined above for the mussel production areas of Saronikos, Thermaikos and Maliakos Gulfs. Slight differences were observed in the Gulf of Kavala, where the highest Dinophysis spp. abundances were recorded in the year 2006, followed by 2005 , although with generally very low values as indicated in the previous section ("Geographical distribution of Dinophysis spp."). Moreover, in the case of Amvrakikos Gulf, the year 2004 also had the highest Dinophysis spp. abundances but this was followed by the year 2005, while no data exist for the year 2003 for this area (Fig. 4c).

The lowest mean Dinophysis spp. counts within the calendar year (Fig. 5) were recorded in late August (fortnight AUG/2). From this point on, a slow but rather steady increase was observed, while the highest values were noted between late March (fortnight MAR/2) and early June (fortnight JUN/1), with an evident peak in early May (fortnight MAY/1). Minor differences in the exact starting time of Dinophysis spp. blooms were observed between the individual years included in the study, but in all cases the highest counts appeared from late winter to spring and the 

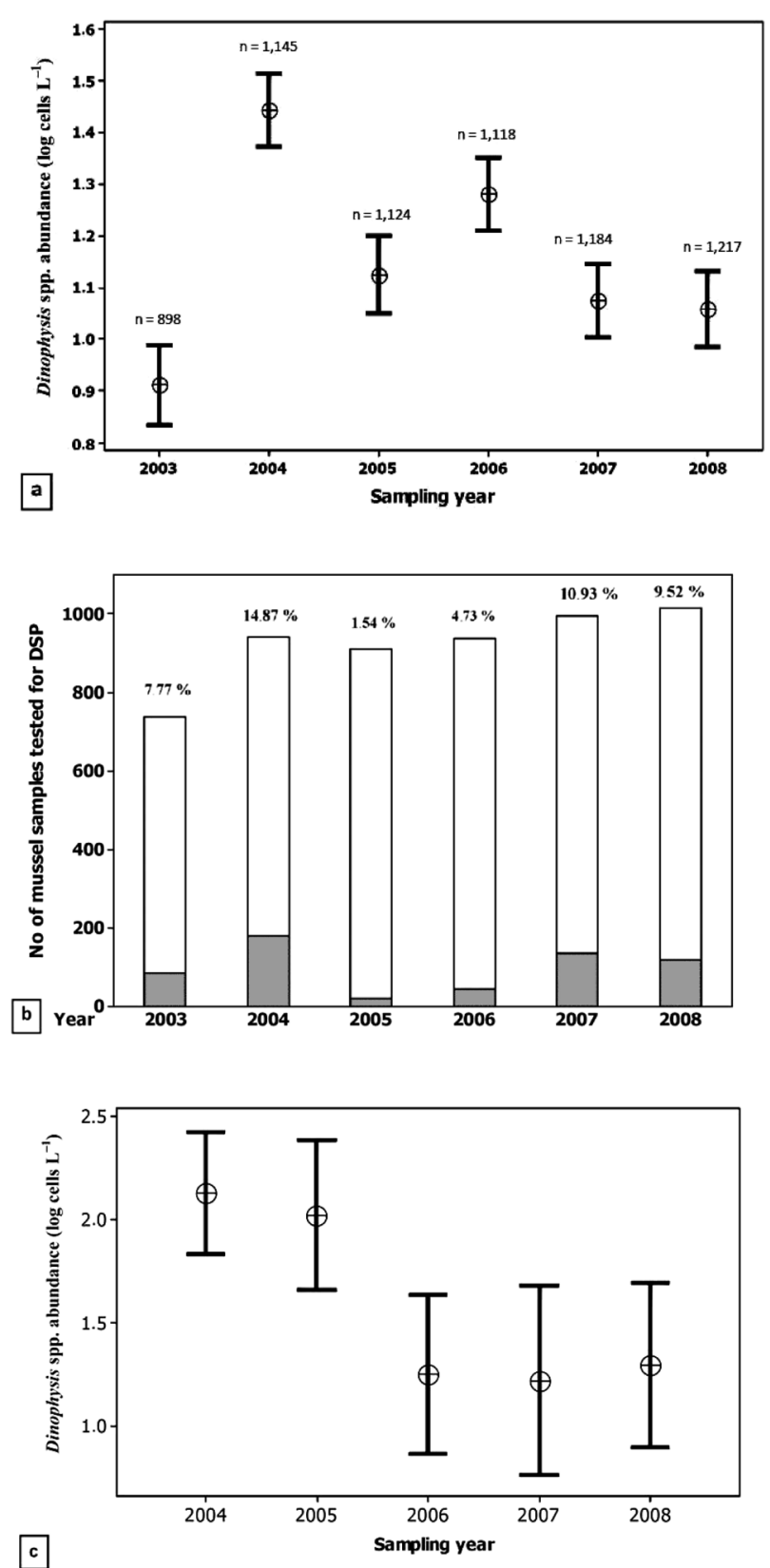

Fig. 4. (a) Dinophysis spp abundance in the total study area, by year $(\oplus$ : mean value; $\perp$ : $95 \%$ confidence interval of the mean). Number of averaged samples $(n)$ per year is presented above each mean value; (b) total counts of DSP positive (filled bars) and negative (unfilled bars) mussel samples and percent rates of DSP positive over total samples during the period 2003 2008, by year; (c) Dinophysis spp. abundance in Amvrakikos Gulf (Prefecture of Preveza), by year $(\oplus$ : mean value; $\perp$ : $95 \%$ confidence interval of the mean).

seasonal periodicity of the phenomenon was evident (Fig. 6). The distribution of the mean number and relevant percent rate of DSP- positive mussel samples during the calendar year indicates that the highest numbers occurred in late winter-spring time (Fig. 7), coinciding with the increase in Dinophysis spp. abundances (Fig. 5). The increase observed in the number of DSP negative and total samples at the time when mussel toxicity tends to decline (MAR/2 to JUN/1; Fig. 7) is a result of the national monitoring programme requirements of three consecutive negative samples at an interval of at least 8 days for the reopening of a closed production area. A second, although minor, increase of DSP positive samples occurred during late summer-autumn, due to the simultaneous increased presence of benthic dinoflagellates, such as Prorocentrum spp. (NRLMB, unpublished data).

\section{Correlation of individual climatological parameters with Dinophysis spp. cell counts}

The whole dataset (individual counts) of Dinophysis spp. abundances exceeding levels leading to closures $\left(\geq 1,000\right.$ cells $\left.\mathrm{L}^{-1}\right)$ were plotted by use of dispersion charts against the climatological parameters studied. Results indicate the following trends for individual parameters:

a) Air temperature: Abundance levels higher than 1,000 cells $\mathrm{L}^{-1}$ were more frequently recorded at air temperatures within the range of $4-20^{\circ} \mathrm{C}$, with the extremes being $-2^{\circ} \mathrm{C}$ and $31^{\circ} \mathrm{C}$, whereas the maximum abundance of Dinophysis spp. $\left(87,280\right.$ cells L $\left.{ }^{-1}\right)$ was recorded at an ambient air temperature of $10^{\circ} \mathrm{C}$ (Fig. 8a). A minor deviation was noted in the mussel production zones of Maliakos Gulf (Fthiotida prefecture), where such abundances were encountered more frequently at a somewhat higher air temperature range, between $15-21^{\circ} \mathrm{C}$, and occurred towards the end of spring/beginning of summer (data not shown). When changes of mean cell abundances of Dinophysis spp. were compared with those of environmental air temperature within the calendar year in an interval plot (Fig. 5), the highest increasing trends were observed in the air temperature range between ca. $10-20^{\circ} \mathrm{C}$, which coincided with two time periods: one between early March and early May (see also the previous section "Temporal variation of Dinophysis spp."), and another between early October and December.

b) Rainfall: Dinophysis spp. cell counts exceeding 1,000 cells $\mathrm{L}^{-1}$ coincided more frequently with drought or low rainfall levels and much less frequently with more intense rainfall (Fig. 8b). Despite the fact that all Dinophysis spp. abundances exceeding 10,000 cells $\mathrm{L}^{-1}$ coincided with rainfall of moderate intensity, it is evident that the majority of closure Dinophysis spp. levels were recorded during periods of light rain or drought.

c) Wind direction: Increased Dinophysis spp. counts leading to regulatory closures were recorded with most wind directions. All three highest cell densities observed coincided with NW winds, followed by the next highest values being encountered with prevailing winds of SE, NE and $\mathrm{N}$ directions (Fig. 8c). Where the yearly pattern of wind directions is observed in relation to Dinophysis spp. abundances (Fig. 6), it is noteworthy that a prevailing SW wind $\left(225^{\circ}\right)$ seems to be present quite regularly around the 


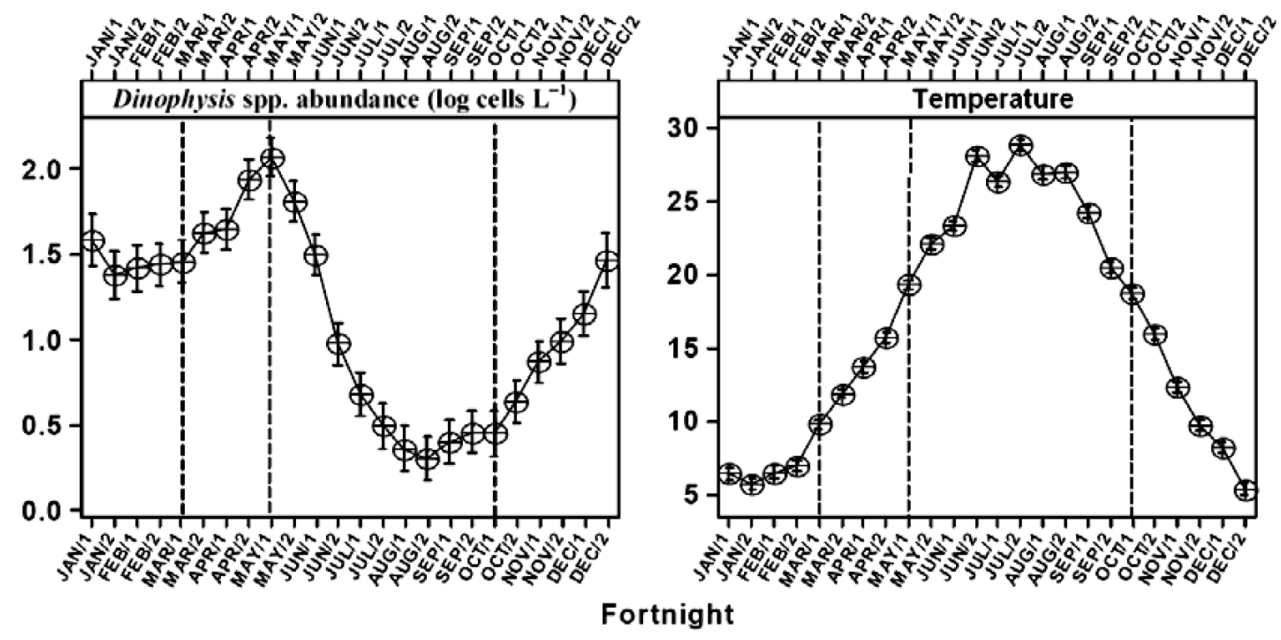

Fig. 5. Dinophysis spp. abundance and ambient air temperature $\left({ }^{\circ} \mathrm{C}\right)$ based on the total dataset of sampled Prefectures during the period 2003-2008 $(\oplus$ : mean value; $\perp$ : 95\% confidence interval of the mean). Vertical dotted lines depict the most important timepoints regarding increase of Dinophysis cell abundances versus air temperature.

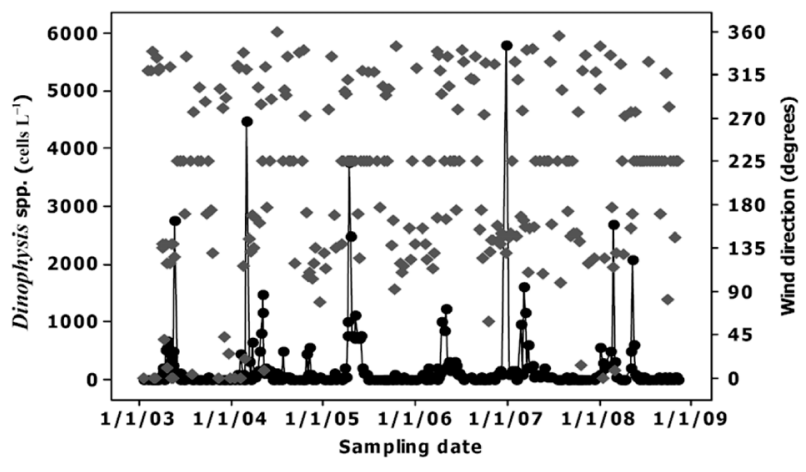

Fig. 6. Dinophysis spp. abundance on each sampling date across the whole study area of Greece during the period 2003 2008 and prevailing wind direction (Dinophysis spp. mean daily count; $\diamond$ : prevailing daily wind direction expressed in degrees).

time that Dinophysis spp. abundances start to decline in the majority of the yearly blooms.

d) Wind velocity: Dinophysis spp. counts higher than 1,000 cells $\mathrm{L}^{-1}$ coincided exclusively with weak (Beaufort 1-2) to moderate (Beaufort 3-4) winds (Fig. 8d). All three highest recorded Dinophysis spp. values $\left(87,280\right.$ cells L ${ }^{-1}$, 86,680 cells $\mathrm{L}^{-1}$ and 76,280 cells $\mathrm{L}^{-1}$ ) were observed in conjunction with wind velocities of Beaufort 1-2.

\section{Combined effects of climatological parameters on Dinophysis spp. cell counts}

The four climatological parameters studied were contour-plotted in pairs together with Dinophysis spp. cell counts [total dataset (individual counts) of the study], in order to investigate the possible existence of combined climatological effects. Contour levels for Dinophysis spp. abundances were selected in order to coincide with the

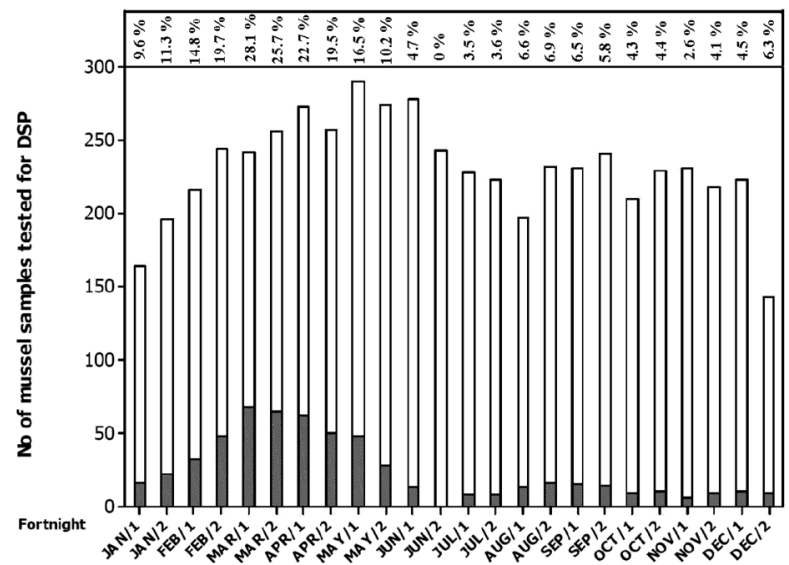

Fig. 7. Distribution of total counts of DSP positive (filled bars) and negative (unfilled bars) mussel samples and percent rates of DSP positive over total samples per fortnight within the calendar year during the period 2003-2008.

nationally established regulatory levels leading to surveillance and/or closure of mussel production areas. All possible combinations of parameters were studied; however only results showing specific trends are presented and further discussed.

a) Wind direction versus time period of the calendar year: Dinophysis spp. cell counts exceeding regulatory closure levels $\left(1,000\right.$ cells $\left.\mathrm{L}^{-1}\right)$ tended to appear in combination with specific wind directions (N, NW, NE and SE) only during winter months (December to February). No other evident tendencies were observed for the remaining months of the year (Fig. 9a).

b) Air temperature versus wind direction: abundances of Dinophysis spp. above the regulatory level of 1,000 cells $\mathrm{L}^{-1}$ were recorded in two separate combinations. The first case was low air temperatures (below $5^{\circ} \mathrm{C}$ ) 

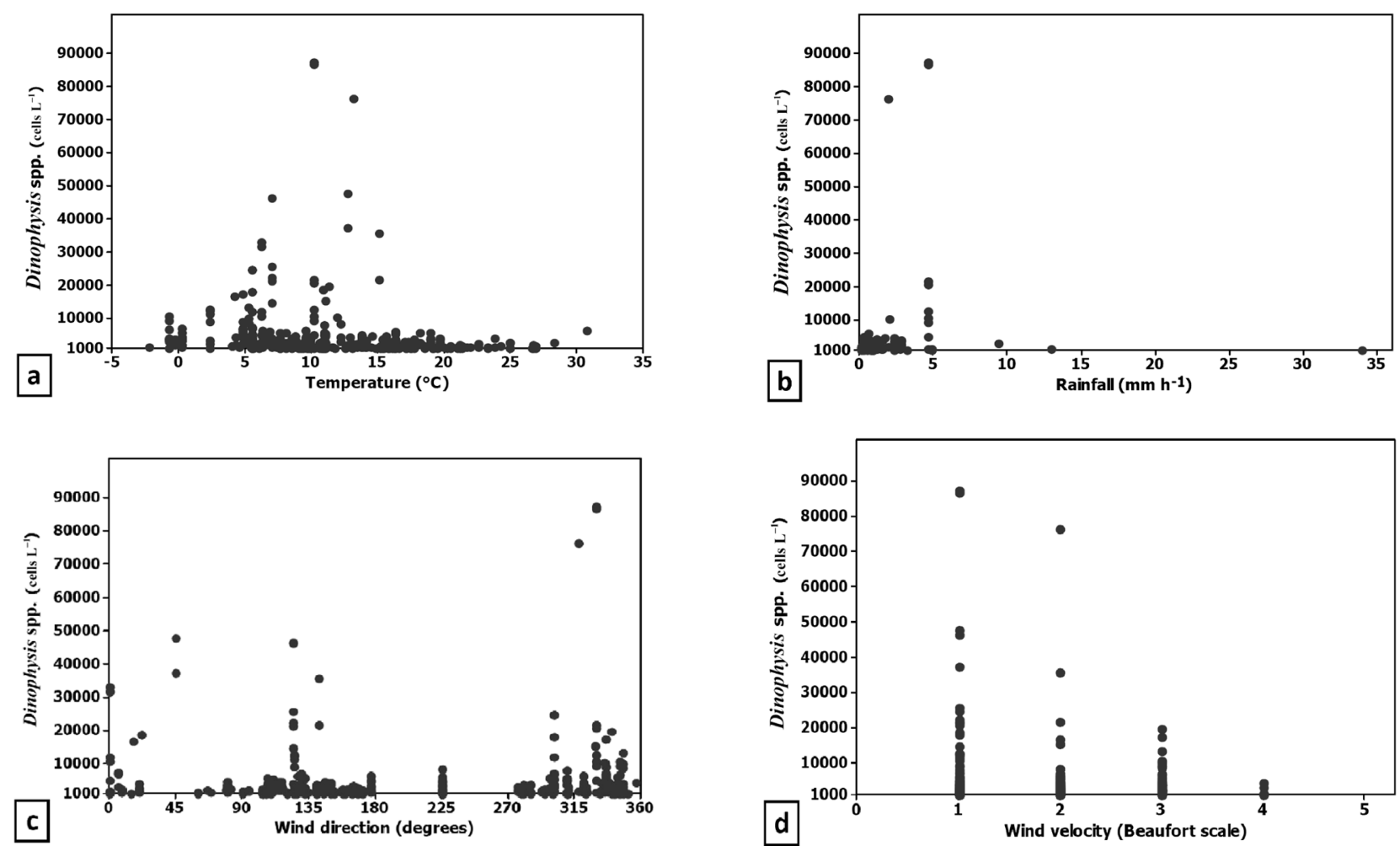

Fig. 8. Dinophysis spp. abundances (dots represent individual counts) at levels exceeding the national regulatory closure limits $\left(\geq 1,000\right.$ cells $\left.\mathrm{L}^{-1}\right)$ versus: (a) air temperature; (b) rainfall; (c) wind direction and (d) wind velocity.

combined with SE prevailing wind directions, while in the second case air temperature ranged between $8-15^{\circ} \mathrm{C}$ and was exclusively associated with $\mathrm{NW}, \mathrm{N}$ and $\mathrm{NE}$ winds (Fig. 9b).

c) Air temperature versus time period of the calendar year: regulatory levels of Dinophysis spp. were exceeded towards the end of the year in combination with air temperature ranges of either $-2-2^{\circ} \mathrm{C}$ or $11-17^{\circ} \mathrm{C}$, whereas in the beginning of the year they coincided with air temperatures between $9-13^{\circ} \mathrm{C}$ (Fig. 9c).

d) Air temperature versus rainfall: increased Dinophysis spp. counts leading to regulatory closures $\left(\geq 1,000\right.$ cells $\left.\mathrm{L}^{-1}\right)$ were recorded in drought periods when air temperature ranged between -2 and $2^{\circ} \mathrm{C}$ or between 18 and $20^{\circ} \mathrm{C}$. When low rainfall occurred, such increased counts occurred in combination with an air temperature of ca. $14^{\circ} \mathrm{C}$, whereas with more intense rainfall similar Dinophysis spp. abundances were recorded at an air temperature range of $9-12^{\circ} \mathrm{C}$ (Fig. 9d).

e) Wind direction versus wind velocity: counts of Dinophysis spp. exceeding 1,000 cells L ${ }^{-1}$, tended to occur with a combination of low velocity wind (Beaufort 1) blowing from the NE and NW directions (Fig. 9e).

\section{Correlation of parameters influencing the occurrence of DSP toxic episodes}

Results of the principal components' analysis (PCA) are summarized in Table 3 and Figure 10. Analysis of the correlation matrix indicated that the first four PCs (PC1, PC2, PC3 and PC4) complied with the set criteria, accounting in total for a proportion of $78.6 \%$ of the data variance (Table $3)$. Proportions of accounted variance, together with the loading factors of the parameters studied for each of the PCs, indicate that $\mathrm{PC} 1$, accounting for $25.2 \%$ of the variance is most probably related to the factor of time, expressed either as individual points of time or as seasonality/periodicity. This hypothesis is supported by the fact that the highest loading factor values in this PC belong to the parameters of air temperature and fortnight of the year, which are tightly connected with time and seasonality. The same observation applies for Dinophysis spp. counts which, as shown in previous sections, are also highly influenced by the time of the year with apparent periodicity. As expected, these parameters were strongly correlated (Fig. 10); air temperature and fortnight of the year were strongly positively correlated, and both were negatively correlated with Dinophysis spp. counts. PC2, accounting for $21.8 \%$ of the variance, seems to be related to the interactive influence of wind, with high loading factor values for both wind velocity and direction (Table 3). These two parameters were strongly positively correlated (Fig. 10), whereas there is no apparent connection with either fortnight of the year or Dinophysis spp. counts. PC3 accounted for $16.8 \%$ of the data variance and is evidently strongly related to the 

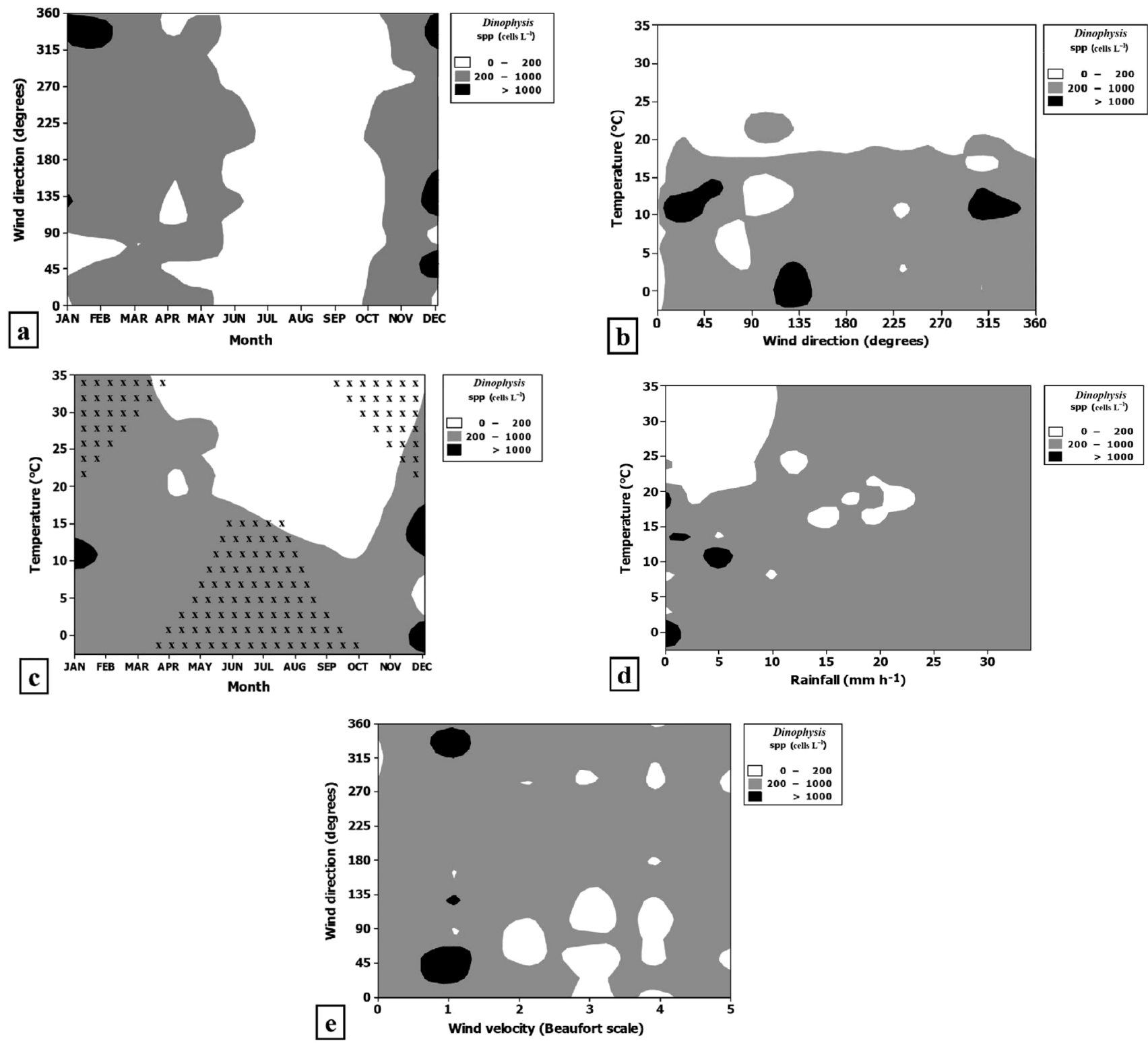

Fig. 9. Dinophysis spp. abundances in relation to: (a) wind direction and time period of the year; (b) air temperature and wind direction; (c) air temperature and time period of the year-graph areas indicated by " $\mathrm{x}$ " represent impossible combinations; (d) air temperature and rainfall; (e) wind direction and velocity.

influence of rainfall on DSP toxic episode occurrence, whereas PC4, accounting for a further $14.8 \%$ of the data variance, was connected with the individual influence of wind direction (Table 3).

\section{Discussion}

\section{Geographical distribution of Dinophysis spp.}

Highest mean counts of potentially toxic Dinophysis spp. during the years 2003-2008 were recorded in the mussel production areas of Thermaikos (Thessaloniki prefecture) and Amvrakikos Gulfs. Nikolaidis et al. (2005), investigating the presence of harmful microalgal episodes in Greek coastal waters in the period 2000-2004, also noted that most blooms occurred in the Thermaikos and Amvrakikos Gulfs. This could be due to intense eutrophication in both areas resulting from increased nutrient inputs from river discharges and/or anthropogenic factors, such as intensive aquaculture, industrial, sewage and landfarming runoff (Balopoulos \& Friligos 1993, Kormas et al. 2001, Sylaios \& Theocharis 2002, Lekka et al. 2004, Dolapsakis et al. 2008). On the other hand, the significantly lower Dinophysis spp. abundances in the mussel production zones of Saronikos (Prefecture of Dytiki Attiki), Western Thermaikos (Prefectures of Imathia and 
Table 3. Principal Component Analysis (PCA): Eigenanalysis of the correlation matrix to investigate contribution of the studied parameters (fortnight of the year, wind direction, air temperature, rainfall, logarithmized Dinophysis spp. counts and wind velocity) and loading factors for the parameters studied (variables) for each of the principal components selected for further analysis by PCA. Bold characters indicate statistically significant $(P \leq 0.05)$ contributions within a principal component.

\begin{tabular}{|c|c|c|c|c|c|c|}
\hline & \multicolumn{6}{|c|}{ Principal Component (PC) } \\
\hline & PC1 & PC2 & PC3 & PC4 & PC5 & PC6 \\
\hline Eigenvalue & 1.5109 & 1.3084 & 1.0085 & 0.8901 & 0.7220 & 0.5601 \\
\hline Proportion of variance accounted for & 0.252 & 0.218 & 0.168 & 0.148 & 0.120 & 0.093 \\
\hline $\begin{array}{l}\text { Cumulative proportion of variance accounted } \\
\text { for }\end{array}$ & 0.252 & 0.470 & 0.638 & 0.786 & 0.907 & 1.000 \\
\hline \multicolumn{7}{|l|}{ Variable } \\
\hline Fortnight of year & 0.490 & 0.424 & -0.147 & -0.133 & & \\
\hline Wind direction & 0.138 & -0.521 & -0.206 & -0.769 & & \\
\hline Air temperature & 0.617 & -0.150 & 0.145 & 0.384 & & \\
\hline Rainfall & -0.020 & -0.122 & -0.936 & 0.325 & & \\
\hline LOG-Dinophysis spp. & -0.504 & -0.324 & 0.117 & 0.277 & & \\
\hline Wind velocity & 0.327 & -0.638 & 0.156 & 0.246 & & \\
\hline
\end{tabular}

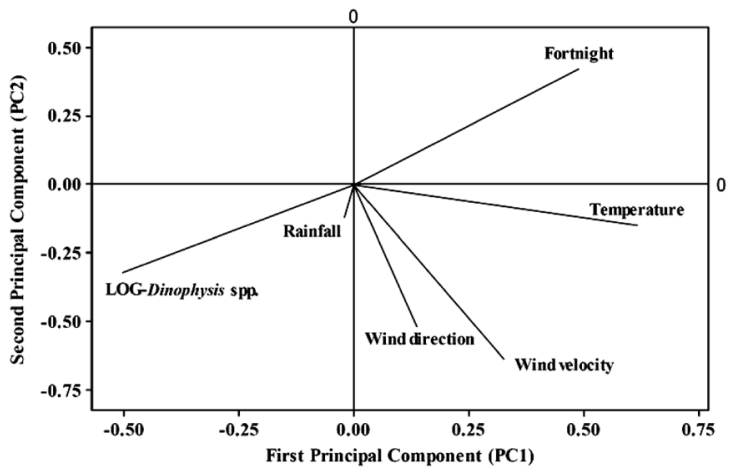

Fig. 10. Correlation matrix presenting the loading factors of the parameters influencing DSP toxic episode occurrence tested by the Principal Components' Analysis (PCA). Only the first (PC1) and second (PC2) principal components are depicted. Proportions of variance accounted for: $\mathrm{PC} 1=25.2 \%, \mathrm{PC} 2=21.8 \%$, PC $3=16.8 \%$, PC4 $=14.8 \%$.

Pieria) and Maliakos Gulfs (Prefecture of Fthiotida) may be attributed to the more open character of Saronikos and Maliakos Gulfs, whereas the mussel production zones of western Thermaikos are located in the central and external parts of the Gulf where hydrographic conditions differ to those of the inner part of the Gulf (Balopoulos \& James 1984). The latter observation is also confirmed by the study of Koukaras \& Nikolaidis (2004) reporting lower abundance levels of $D$. cf. acuminata at the sampling stations of Pieria and Imathia (Thermaikos Gulf), possibly as a result of dilution of coastal waters with offshore waters from the North Aegean Sea. This is further supported by the significantly lower Dinophysis spp. abundances in the Gulf of Kavala (present study), a particularly open gulf with reduced input of nutrients from freshwater discharges.
The significant differences in Dinophysis spp. cell counts leading to the observed sampling station "grouping" in the mussel production areas of Thermaikos Gulf, of the Thessaloniki prefecture jurisdiction, are also in agreement with the findings of Koukaras \& Nikolaidis (2004), who reported the outer parts of Thermaikos Gulf (middle and southern parts) always have significantly lower numbers of Dinophysis cells than in the inner gulf. In the same context, Balopoulos \& Friligos (1993) recorded significant differences in inorganic nutrient concentrations between the Gulf of Thessaloniki and the central and external parts of Thermaikos Gulf, with the highest values obtained in the Gulf of Thessaloniki, followed by northwestern Thermaikos and southeastern Thermaikos Gulf. The highest values, measured in the Gulf of Thessaloniki, were mainly attributed to the discharge of unprocessed urban waste from the city of Thessaloniki in the inner part of the Gulf (Nikolaidis et al. 2006) and could also point to a connection with the long durations of regulatory closures observed in the mussel production areas of the western Thermaikos Gulf.

On the other hand, cell count differences among sampling areas could be attributed to a number of factors influencing water column stability (stratification), such as water circulation, bottom morphology/topography and depth, which lead to different patterns of vertical mixing/turbulence, as for instance it is known that Dinophysis spp. counts start to increase when there is water column stability (Maestrini 1998). Furthermore, thin layer formation during marked stratification or intense physical accumulation forced by upwelling relaxation, which are commonly reported for Dinophysis spp., should also be taken into account. Since in the present study the entire water column was sampled with a tube, the factor of individual depths could also play a role in the significantly different Dinophysis counts observed between areas (Reguera et al. 2012). 


\section{Temporal distribution of Dinophysis spp.}

Significant differences between mean counts of potentially toxic Dinophysis spp. during the years 2003-2008 might be attributed to yearly differences in climatological and hydrological parameters, which could - influence nutrient availability in the respective areas and/or change the water column conditions, as disruption of the latter seems to have an important impact on growth of Dinophysis spp. (Estrada \& Berdalet 1997, Vale \& Sampayo 2003). Moreover, such parameters could also affect growth and availability of species used as prey by Dinophysis, such as the ciliate Mesodinium rubrum (Lohmann, 1908) [synonym Myrionecta rubra (Jankowski, 1976)], as well as competition between species (Crawford \& Lindholm 1997, Park et al. 2006). For example, four Dinophysis species [D. acuminata (Claparède \& Lachmann, 1859), D. caudata (SavilleKent, 1881), D. fortii (Pavillard, 1923) and D. infundibulus (Schiller, 1928)] feed on the marine ciliate M. rubra when grown with the cryptophyte Teleaulax (Park et al. 2006, Nishitani et al. 2008, Nagai et al. 2008). Relevant experimental data clearly showed that these species could not grow by ingestion of only the Teleaulax sp. but instead required $M$. rubra as prey for enabling their vegetative growth and sequestering the ciliate plastids in order to utilize them as kleptoplastids (Nagai et al. 2008). Kamiyama et al. (2010) and Nagai et al. (2011) clarified that toxin production by Dinophysis species was confirmed only when they fed on M. rubra as the food source, indicating that abundances of the latter species are also very important for Dinophysis in order to grow and produce toxins in natural environments.

On the other hand, the lack of agreement between yearly Dinophysis spp. counts and the intensity of the relevant DSP toxic episodes in mussels, indicated by the number of DSP positive samples per year, may be attributable to a number of reasons, such as variation in toxin production capacity of implicated Dinophysis species, the possible existence of different strains of a single species with variable dominance between different years, and fluctuating abundance of other phytoplankton species which could also be ingested by the mussels. Furthermore, there were fluctuations in the numbers of mussel samples received for testing, as well as fluctuations in the relative contribution of DSP-positive samples originating from benthic dinoflagellates (e.g. Prorocentrum spp.), which is a quite common phenomenon in late summer-autumn periods in Greek coastal areas (Vlamis et al. 2010, NRLMB, unpublished data). It is noted that both the sampling method (entire water column) as well as the cell counting method employed (as defined by the relevant legislation) result in certain limitations which could influence both apparent spatial variation in cell counts and the lack of a relationship between cell density and the occurrence of DSPpositive mussel samples. Natural populations of Dinophysis cells are known to aggregate within thin layers; there- fore by sampling the entire water column, the number of cells in contact with the mussel stock may be under or overestimated. In addition, the use of a pipe or hose to sample the entire water column, could cause a "dilution effect", which could be enhanced at sampling sites with greater depth. Furthermore, the counting method involves Dinophysis determination at the genus level rather than recognition of individual species, thus ignoring differences in toxin profiles and concentrations between cells of different species. These two limitations need to be taken into account when discussing issues like spatial variation in cell counts and the lack of an apparent of relationship between cell density and the occurrence of DSP-positive mussels samples (Reguera et al. 2012).

During the whole study period (2003-2008), Dinophysis spp. presence followed an evident periodicity within the calendar year in most of the areas studied, with maximum abundances recorded in the winter-spring months and negligible abundances in summer and autumn. Seasonal periodicity has also been reported in other studies from the Thermaikos Gulf, Greece (Koukaras \& Nikolaidis 2004, Nikolaidis et al. 2005), several European countries (Bernardi Aubry et al. 2000, Vale \& Sampayo 2003, France \& Mozetič 2006, Ninčević-Gladan et al. 2008), and worldwide (Koike et al. 2000, Morton et al. 2009, Swanson et al. 2010). The only deviation between studies from different countries concerns the exact time period in which maximum abundances occur within the calendar year, which is a result of differences in the timing of seasonal climate periodicity and hydro-chemical parameters in different geographic regions.

\section{Effect of climatological parameters on Dinophysis spp. counts}

\section{Air temperature}

The trend of Dinophysis spp. presence increasing within the air temperature range of $10-20^{\circ} \mathrm{C}$, as well as the more frequent occurrence of abundances exceeding 1,000 cells $\mathrm{L}^{-1}$ when air temperatures ranged between $4^{\circ} \mathrm{C}$ and $20^{\circ} \mathrm{C}$, at least in the mussel production zones of Thermaikos and Saronikos Gulfs, is connected to the fact that $D$. cf. acuminata is the dominant Dinophysis species in these areas (Koukaras \& Nikolaidis 2004, Nikolaidis et al. 2005, LUTMM, personal communication).This a species has a preference for seawater temperatures common during the winter and spring months (Table 4) in Greece (Ninčević-Gladan et al. 2008). In a recent study, Papaefthimiou et al. (2010), using ribosomal and mitochondrial genetic sequence data, re-identified the $D$. cf. acuminata described from Greek coastal waters as D. cf. ovum (Schütt, 1895), a species belonging to the same complex. In agreement with our findings, maximum abundances of $D$. cf. acuminata have been recorded at the seawater temperature range of $12-16^{\circ} \mathrm{C}$ in Thermaikos Gulf in the years 2000 2002 (Koukaras \& Nikolaidis 2004), and other researchers have also reported similar seawater temperature ranges for 
Table 4. Winter and spring seawater temperatures of the Greek Gulfs included in the study, according to the available bibliography.

\begin{tabular}{|c|c|c|c|}
\hline Coastal area & Season & Water temperature range $\left({ }^{\circ} \mathrm{C}\right)$ & Reference \\
\hline \multirow{3}{*}{ Thermaikos Gulf } & Winter & $11.5-12.5$ & \multirow{3}{*}{ Koukaras \& Nikolaidis (2004) } \\
\hline & & & \\
\hline & Spring & $13-16$ & \\
\hline \multirow{3}{*}{ Saronikos Gulf } & Winter & $12.5-15$ & \multirow{3}{*}{ Siokou-Frangou et al. (1998) } \\
\hline & & & \\
\hline & Spring & $14-16$ & \\
\hline \multirow{3}{*}{ Amvrakikos Gulf } & Winter & $12-13$ & \multirow{3}{*}{ Vareli et al. (2012) } \\
\hline & & & \\
\hline & Spring & $18-20$ & \\
\hline \multirow{3}{*}{ Gulf of Kavala } & Winter & $11-12.5$ & \multirow{3}{*}{ Sylaios et al. (2005) } \\
\hline & & & \\
\hline & Spring & $12-20$ & \\
\hline \multirow{3}{*}{ Maliakos Gulf } & Winter & $11.8-14.1$ & \multirow{3}{*}{ Kormas et al. (2002) } \\
\hline & & & \\
\hline & Spring & $16.9-23.9$ & \\
\hline
\end{tabular}

maximum counts of Dinophysis spp. when D. acuta (Ehrenberg, 1840), D. acuminata or D. norvegica (Claparède \& Lachmann, 1859) were the species responsible for the blooms (Reguera et al. 1995, Godhe et al. 2002, Díaz et al. 2011).

In Maliakos Gulf, abundances of Dinophysis spp. higher than 1,000 cells $\mathrm{L}^{-1}$ were more frequently recorded when the air temperature ranged between $15-21^{\circ} \mathrm{C}$, probably due to the fact that D. sacculus (Stein 1883) and D. caudata, the growth of which is favored at slightly higher seawater temperatures, constitute the dominant Dinophysis species in this area (Bernardi Aubry et al. 2000, Koukaras \& Nikolaidis 2004, Nikolaidis et al. 2005, France \& Mozetič 2006). Similarly, maximum abundances of $D$. sacculus and D. caudata have been systematically recorded in the warmer seasons of the year by other researchers (Bernardi Aubry et al. 2000, Caroppo 2001, France \& Mozetič 2006, Ngyuen et al. 2006).

Temperature is the most important factor affecting growth of Dinophysis spp. (Reguera et al. 1995). Consequently, the observed differences in seasonality with regard to development of the same or closely related Dinophysis species between different areas and/or countries are actually related to the exact time periods when the optimum temperature range is reached due to variation in local climatological conditions. Nevertheless, the influence of other environmental conditions such as water stability due to thermal stratification and/or prevalence of low winds and low rainfall, which occur during periods of the year when the air temperature is indicative of periods when mussel stocks are more susceptible to the occurrence of DST contamination), should not be neglected, as it is possible that there is no direct cause-effect relationship between air temperature and shellfish toxicity.

\section{Wind direction and velocity}

Maximum Dinophysis spp. abundances in the present study occurred during a variety of prevailing wind directions, but were mostly correlated with northern (NW, N and NE) and southern (SE and S) directions and were generally favored by low velocity winds up to Beaufort 4. Prevailing wind direction is closely related to the phenomena of upwelling and downwelling, as well as with changes in water circulation (Escalera et al. 2010). Reports in the literature are often controversial with regard to specific wind directions favoring the development of Dinophysis spp., as well as of other dinoflagellates, but there is a rather general consensus that the main controllers of Dinophysis spp. growth, in agreement with our findings, are connected to winds blowing from northern and southern directions and affecting the phenomena of water upwelling and downwelling (Reguera et al. 1995, Blanco et al. 1998, Tilstone et al. 2000, Reguera 2003, Velo-Suárez et al. 2008). Reguera (2003) specifically indicated that high concentrations of Dinophysis spp. can develop after wind reversal (from northerlies promoting upwelling, to southerlies favouring downwelling events); in the latter case, high abundances are the result of physical accumulation (interacting with behaviour) rather than of active vegetative growth. It is highly possible that such influences are regulated by the particular climatological conditions and geomorphology of each of the different areas under investigation. In agreement with the results of the present study where increased abundances of Dinophysis spp. coincided with winds of low velocity, Estrada \& Berdalet (1997) have pointed out that dinoflagellates generally have higher mean abundances during periods of calmness, in contrast to diatoms, which are favored by the presence of intense winds. 


\section{Rainfall}

Results of the present study indicated that Dinophysis spp. abundances exceeding the established closure limit of 1,000 cells $\mathrm{L}^{-1}$ were more frequently recorded in conjunction with drought or low rainfalls. Vale \& Sampayo (2003), who studied the effects of rainfall on the seasonality of DSP in Aveiro lagoon, Portugal, concluded that low rainfall volume, preceded by heavy rainfall that would lead to a higher nutrient input into the basin, was associated with higher D. acuminata abundances and the occurrence of more intense DSP toxic episodes. Rainfall was identified as an extremely important factor controlling in situ blooms of toxic Dinophysis spp. and consequently its toxicity implications in shellfish in Aveiro lagoon. Lowering of rainfall resulted in lower river drainage, which translated into higher salinity and increased stability of the water column inside the lagoon. Growth of Dinophysis spp. and dinoflagellates in general, is reported to be closely connected to water column stability. Consequently, factors that contribute to limiting water column disruption, such as low rainfall, can be favorable for dinoflagellate development (Estrada \& Berdalet 1997). The findings of Vale \& Sampayo (2003) are in partial agreement with those of the present study, excepting that no cases of heavy rainfall preceding the low rainfall periods when Dinophysis spp. reached their maxima were observed in the present study (data not shown). This difference is attributed to both the specific conditions of the study area, as well as to the fact that Greece is a country with generally low rainfall. Aveiro lagoon is characterized as a complex network structure with an intertidal morphology and, furthermore, lagoons are considered to be productive ecosystems where the hydrological conditions and water salinity can change rapidly due to geomorphology (Lopes \& Dias 2007). In contrast, open systems such as the gulfs in our study, have geomorphological, hydrographic and dynamic differences that do not always allow for easy intercomparisons (ÁlvarezSalgado et al. 2011). In this context, the model proposed by Vale (2012) for predicting DSP contamination according to rainfall accumulation during the months preceding the relevant toxic episodes would be of limited use in the case of Greek coastal areas.

\section{Combined effects of climatological parameters}

Development of Dinophysis spp. blooms and highest abundances were mainly favored by two combinations of climatological parameters: a) northerly winds at air temperatures between $10-15^{\circ} \mathrm{C}$ during the initial months of the calendar year and b) southerly or south-easterly winds with lower air temperatures within the range of $-2^{\circ} \mathrm{C}$ and $2^{\circ} \mathrm{C}$ towards the end of the calendar year. Both combinations also involved winds of low velocity and rainfall ranging from drought to low levels. These findings obviously do not constitute the exclusive conditions that may favour the development of Dinophysis spp. blooms in Greek coastal waters, but might be taken as a rough indicator in order to anticipateincreases in Dinophysis spp. abundances.

The principles upon which both the above combinations can be explained are the least possible disruption of water column conditions in conjunction with the presence of a favorable temperature range. The various algal taxonomic groups demonstrate a different level of susceptibility to agitation and therefore changes in water column stability, with an ascending order of sensitivity as follows: chlorophytes, Cyanobacteria, diatoms and dinoflagellates (White 1976, Thomas \& Gibson 1990, Petersen et al. 1998). This is further confirmed by observations in the natural environment where the presence of dinoflagellates is connected with areas exhibiting minimal disturbance (Margalef 1978, Estrada \& Berdalet 1997). In agreement, therefore, to the findings of our study, climatological conditions disrupting water column stability, such as strong winds and heavy rainfall, are not considered in the literature as a favorable environment for dinoflagellates, and thus for species belonging to the genus Dinophysis.

\section{Conclusion}

Harmful blooms of Dinophysis spp. in Greek coastal waters during the period 2003-2008, showed a clearly evident periodicity, peaking in the winter and spring months, with highest counts recorded regularly in winter and spring months and a negligible presence in the summer and autumn months of the year. The highest Dinophysis spp. abundances were recorded in Amvrakikos and Thermaikos Gulfs, and specifically in the Gulf of Thessaloniki, while the lowest values occurred in the Gulf of Kavala. Air temperature seemed to be highly correlated with Dinophysis spp. presence; maximum counts coincided with the air temperature range of $10-20^{\circ} \mathrm{C}$, while abundances exceeding the nationally established limits for closure of mussel production areas $\left(\geq 1,000\right.$ cells $\left.\mathrm{L}^{-1}\right)$ were more frequently recorded at air temperatures between $4-20^{\circ} \mathrm{C}$. Northerly (NW, N and NE) and southerly (SE and S) wind directions and low wind velocities generally favored the presence of Dinophysis spp., whereas maximum counts occurred mostly coinciding with drought or low rainfall. Such observations, derived from historical monitoring data, could be of significant value with regard to clarification of DSP toxic episode occurrence patterns and might subsequently lead to better economical management of mussel production.

\section{Acknowledgements}

The authors are grateful to Mr. Dimitrios Petridis (Technological Educational Institute of Thessaloniki, Greece) for expert advice on statistical analysis and to Dr. Katerina Aligizaki (Laboratory Unit of Toxic Marine Microalgae, Aristotle University of Thessaloniki, Greece) for useful comments during the study. The collaboration of all staff of the National Reference Laboratory of Marine Biotoxins 
is also greatly appreciated. Thanks are also expressed to (a) the General Veterinary Directorate of the MRDF for approving this study and (b) all the relevant prefectural veterinary services for their contribution to the shellfish samplings and for provision of the seawater analysis determining results for the presence of potentially toxic microalgae.

\section{References}

Álvarez-Salgado XA, Figueiras FG, Fernández-Reiriz MJ, Labarta U, Peteiro L, Piedracoba S (2011) Control of lipophilic shellfish poisoning outbreaks by seasonal upwelling and continental runoff. Harmful Algae 10: 121-129.

American Meteorological Society (2012) Glossary of Meteorology: Rain. Available at: http:/glossary.ametsoc.org/wiki/Rain (accessed on 25 August 2013)

Balopoulos ET, Friligos NC (1993) Water circulation and eutrophication in the northwestern Aegean Sea: Thermaikos Gulf. J Environ Sci Heal 28: 1311-1329.

Balopoulos ET, James AE (1984) Surface currents in the NW Aegean (Greece) as shown from the movement of driftcards. VIIex Journees Etud Pollution, Lucerne, C.I.E.S.M., pp. 129 138.

Bernardi Aubry F, Berton A, Bastianini M, Bertaggia R, Baroni R, Socal G (2000) Seasonal dynamics of Dinophysis in coastal waters of the NW Adriatic Sea (1990-1996). Bot Mar 43: 423430.

Blanco J, Moroño A, Pazos Y, Maneiro J, Mariño J (1998) Trends and variations of the abundance of main PSP and DSP producing species in the Galician Rías: Environmental and biological influences. In: Harmful algae (eds Reguera B, Blanco J, Fernandez ML, Wyatt T). Xunta de Galicia and Intergovernmental Oceanographic Commission of UNESCO, Paris, pp. 204207.

Caroppo C (2001) Autoecology and morphological variability of Dinophysis sacculus (Dinophyceae: Dinophysiaceae) in a Mediterranean lagoon. J Mar Biol Assoc UK 81: 11-21.

Crawford DW, Lindholm T (1997) Some observations on vertical distribution and migration of the phototrophic ciliate Mesodinium rubrum (=Myrionecta rubra) in a stratified brackish inlet. Aquat Microb Ecol 13: 267-274.

Dahl E, Johannessen T (2001) Relationship between occurrence of Dinophysis species (Dinophyceae) and shellfish toxicity. Phycologia 40: 223-227.

Daranas AH, Norte M, Fernández JJ (2001) Toxic marine microalgae. Toxicon 39: 1101-1132.

Díaz P, Molinet C, Cáceres M, Valle-Levinson A (2011) Seasonal and intratidal distribution of Dinophysis spp. in a Chilean fjord. Harmful Algae 10: 156-164.

Dolapsakis NP, Tzovenis I, Kantourou P, Bitis I, EconomouAmilli A (2008) Potentially harmful microalgae from lagoons of the NW Ionian Sea, Greece. J Biol Res-Thessalon 9: 89-95.

Escalera, L, Reguera B, Moita T, Pazos Y, Cerejo M, Cabanas J, Ruiz-Villarreal M (2010) Bloom dynamics of Dinophysis acuta in an upwelling system: In situ growth versus transport. Harmful Algae 9: 312-322.
Estrada M,. Berdalet E (1997) Phytoplankton in a turbulent world. Sci Mar 61: 125-140.

EU Directive 86/609/EEC (1986) Council Directive 86/609/EEC of 24 November 1986 on the approximation of laws, regulations and administrative provisions of the Member States regarding the protection of animals used for experimental and other scientific purposes. Off J Eur Commun L358: 1-28.

EU Recommendation 2007/526/EC (2007) Commission Recommendation of 18 June 2007 on guidelines for the accommodation and care of animals used for experimental and other scientific purposes. Off J Eur Union L197: 1-89.

EU Regulation 854/2004/EC (2004) Regulation (EC) No $854 / 2004$ of the European Parliament and of the Council of 29 April 2004 laying down specific rules for the organisation of official controls on products of animal origin intended for human consumption. Off J Eur Union L139: 206-320.

EU Regulation 2074/2005/EC (2005) Commission Regulation (EC) No 2074/2005 of 5 December 2005 laying down implementing measures for certain products under Regulation (EC) No 853/2004 of the European Parliament and of the Council and for the organization of official controls under Regulation (EC) No 854/2004 of the European Parliament and of the Council and Regulation (EC) No 882/2004 of the European Parliament and of the Council, derogating from Regulation (EC) No 852/2004 of the European Parliament and of the Council and amending Regulations (EC) No 853/2004 and (EC) No 854/2004. Off J Eur Union L 338: 27-59.

France J, Mozetič P (2006) Ecological characterization of toxic phytoplankton species (Dinophysis spp., Dinophyceae) in Slovenian mariculture areas (Gulf of Trieste, Adriatic Sea) and the implications for monitoring. Mar Pollut Bull 52: 15041516.

Godhe A, Svensson S, Rehnstam-Holm AS (2002) Oceanographic settings explain fluctuations in Dinophysis spp. and concentrations of diarrhetic shellfish toxin in the plankton community within a mussel farm area on the Swedish west coast. Mar Ecol Prog Ser 240: 71-83.

Hallegraeff G (1993) A review of harmful algal blooms and their apparent global increase. Phycologia 32: 79-99.

Hallegraeff G, Lucas I (1988) The marine dinoflagellate genus Dinophysis (Dinophyceae): photosynthetic, neritic and nonphotosynthetic, oceanic species. Phycologia 27: 25-42.

Hoshiai G, Chiba M, Onodera T (1996) Kaidoku seibun · yudoku plankton tou monitoring jigyo houkokusho [Report of monitoring project on shellfish toxins and harmful plankton]. Kesennuma Miyagi Prefectural Fisheries Experimental Station, Japan, 37 pp. (in Japanese)

Joliffe IT (2002) Principal Component Analysis 2nd ed. Springer Statistics, New York, 487 pp.

Kamiyama T, Nagai S, Suzuki T, Miyamura K (2010) Effect of temperature on production of okadaic acid, dinophysistoxin-1, and pectenotoxin-2 by Dinophysis acuminata in culture experiments. Aquat Microb Ecol 60: 193-202.

Kara BA, Robert HW, Timothy BP, James EB (2009) Mixed layer depth in the Aegean, Marmara, Black and Azov Seas: Part I: General features. J Mar Syst 78: 169-180.

Koike K, Koike K, Takagi M, Ogata T, Ishimaru T (2000) Evidence of phagotrophy in Dinophysis fortii (Dinophysiales, Di- 
nophyceae), a dinoflagellate that causes diarrhetic shellfish poisoning (DSP). Phycol Res 48: 121-124.

Kormas KA, Garametsi V, Nicolaidou A (2002) Size-fractionated phytoplankton chlorophyll in an Eastern Mediterranean coastal system (Maliakos Gulf, Greece). Helgoland Mar Res 56:125-133.

Kormas KA, Nicolaidou A, Reizopoulou S (2001) Temporal variations of nutrients, chlorophyll a and particulate matter in three coastal lagoons of Amvrakikos Gulf (Ionian Sea, Greece). PSZNI Mar Ecol 22: 201-213.

Koukaras K, Nikolaidis G (2004) Dinophysis blooms in Greek coastal waters (Thermaikos Gulf, NW Aegean Sea). J Plankton Res 26: 445-457.

Lekka E, Kagalou I, Lazaridou-Dimitriadou M, Albanis T, Dakos V, Lambropoulou D, Sakkas V (2004) Assessment of the water and habitat quality of a Mediterranean river (Kalamas, Epirus, Hellas), in accordance with the EU Water Framework Directive. Acta Hydroch Hydrob 32: 175-188.

Lindahl O, Andersson B (1996) Environmental factors regulating the occurrence of Dinophysis spp. in the Koljö Fjord, Sweden. In: Harmful and Toxic Algal Blooms (eds Yasumoto T, Oshima Y, Fukuyo Y), Intergovernmental Oceanographic Commission of UNESCO, Paris, pp. 269-272.

Lopes JF, Dias JM (2007) Residual circulation and sediment distribution in the Ria de Aveiro lagoon, Portugal. J Mar Syst 68: 507-528.

Louppis A, Badeka A, Katikou P, Paleologos E, Kontominas M (2010) Determination of okadaic acid, dinophysistoxin-1 and related esters in Greek mussels using HPLC with fluorometric detection, LC-MS/MS and mouse bioassay. Toxicon 55: 724733.

Maestrini SY (1998) Bloom dynamics and ecophysiology of Dinophysis spp. In: Physiological Ecology of Harmful Algal Blooms (eds Anderson DM, Cembella AD, Hallegraeff GM). NATO ASI Series, Series G, Ecological Science. SpringerVerlag, Berlin, pp. 243-266.

Margalef R (1978) Life-forms of phytoplankton as survival alternatives in an unstable environment. Oceanol Acta 1: 493-509.

Ministry of Rural Development and Food (2002) MRDF Decision 313153/20-12-2002: National Program for Monitoring of Bivalve Molluscs' Production Areas for the presence of Marine Biotoxins. Ministry of Rural Development and Food, Athens, 10 pp. (in Greek)

Moita MT, Da Silva AJ (2001) Dynamics of Dinophysis acuta, D. acuminata, D. tripos and Gymnodinium catenatum during an upwelling event off the northwest coast of Portugal. In: Harmful Algal Blooms 2000 (eds Hallegraeff GM, Blackburn SI, Bolch CJ, Lewis RJ). Intergovernmental Oceanographic Commission of UNESCO, Paris, pp. 169-172.

Morton SL, Vershinin A, Smith LL, Leighfield TA, Pankov S, Quilliam MA (2009) Seasonality of Dinophysis spp. and Prorocentrum lima in Black Sea phytoplankton and associated shellfish toxicity. Harmful Algae 8: 629-636.

Mouratidou T, Kaniou-Grigoriadou I, Samara C, Koumtzis T (2004) Determination of okadaic acid and related toxins in Greek mussels by HPLC with fluorimetric detection. J Liq Chromat Rel Technol 27: 2153-2166.

Nagai S, Nishitani G, Tomaru Y, Sakiyama S, Kamiyama T
(2008) Predation by the toxic dinoflagellate Dinophysis fortii on the ciliate Myrionecta rubra and observation of sequestration of ciliate chloroplasts. J Phycol 44: 909-922.

Nagai S, Suzuki T, Nishikawa T, Kamiyama T (2011) Differences in the production and excretion kinetics of okadaic acid, dinophysistoxin-1, and pectenotoxin-2 between cultures of Dinophysis acuminata and Dinophysis fortii isolated from western Japan. J Phycol 47: 1326-1337.

Nguyen HB, Corbett SW, Menes K, Cho T, Daugharthy J, Klein W, Wittlake WA (2006) Early goal-directed therapy, corticosteroid, and recombinant human activated protein $\mathrm{C}$ for the treatment of severe sepsis and septic shock in the emergency department. Acad Emerg Med 13: 109-113.

Nikolaidis G, Koukaras K, Aligizaki K, Heracleous A, Kalopesa E, Moschandreou K, Tsolaki E, Mantoudis A (2005) Harmful microalgal episodes in Greek coastal waters. J Biol Res-Thessalon 3: 77-85.

Nikolaidis NP, Karageorgis AP, Kapsimalis V, Marconis G, Drakopoulou P, Kontoyiannis H, Krasakopoulou E, Pavlidou A, Pagou K (2006) Circulation and nutrient modeling of Thermaikos Gulf, Greece. J Mar Syst 60: 51-62.

Ninčević-Gladan Ž, Skejić S, Bužančić M, Marasović I, Arapov J, Ujević I, Bojanić N, Grbec B, Kušpilić G, Vidjak O (2008) Seasonal variability in Dinophysis spp. abundances and diarrhetic shellfish poisoning outbreaks along the eastern Adriatic coast. Bot Mar 51: 449-463.

Nishitani G, Nagai S, Sakiyama S, Kamiyama T (2008) Successful cultivation of the toxic dinoflagellate Dinophysis caudata (Dinophyceae). Plankton Benthos Res 3: 78-85.

Papaefthimiou D, Aligizaki K, Nikolaidis G (2010) Exploring the identity of the Greek Dinophysis cf. acuminata. Harmful Algae 10: 1-8.

Park MG, Kim S, Kim HS, Myung G, Kang YG, Yih W (2006) First successful culture of the marine dinoflagellate Dinophysis acuminata. Aquat Microb Ecol 45: 101-106.

Paz B, Riobo P, Fernandez AL, Fraga S, Franco JM (2004) Production and release of yessotoxins by the dinoflagellates Protoceratium reticulatum and Lingulodinium polyedrum in culture. Toxicon 44: 251-258.

Petersen JE, Sanford LP, Kemp WM (1998) Coastal plankton responses to turbulent mixing in experimental ecosystems. Mar Ecol Prog Ser 171: 23-41.

Petridis D (2000) Applied Statistics in Food Science, 2nd Edition. Omiros Publications, Thessaloniki, 517 pp. (in Greek)

Poulos S, Drakopoulos P, Collins M (1997) Seasonal fluctuations in sea surface temperature, water budgets and circulation patterns in the Aegean Sea (eastern Mediterranean): an overview. J Mar Syst 13: 225-244.

Prassopoulou E, Katikou P, Georgantelis D, Kyritsakis A (2009) Detection of okadaic acid and related esters in mussels during diarrhetic shellfish poisoning (DSP) episodes in Greece using the mouse bioassay, the PP2A inhibition assay and HPLC with fluorimetric detection. Toxicon 53: 214-227.

Reguera B (2003) DSP outbreak caused by low concentrations of Dinophysis spp.: what can remote sensing do to help monitoring of these events. Workshop on Red Tide Monitoring in Asian Coastal Waters, March 10-12, 2003, Tokyo, Japan. Available at: http://fol.fs.a.u-tokyo.ac.jp/rtw/TOP/EXabst/026BReguera.pdf 
(accessed on 7/5/2013)

Reguera B, Bravo I, Fraga S (1995) Autoecology and some life history stages of Dinophysis acuta Ehrenberg. J Plankton Res 17: 999-1015.

Reguera B, Velo-Suárez L, Raine R, Park M (2012) Harmful Dinophysis species: A review. Harmful Algae 14: 87-106.

Siokou-Frangou I, Papathanassiou E, Lepretre A, Frontier S (1998) Zooplankton assemblages and influence of environmental parameters on them in a Mediterranean coastal area. J Plankton Res 20: 847-870.

Swanson K, Flewelling L, Byrd M, Nunez A, Villareal T (2010) The 2008 Texas Dinophysis ovum bloom: Distribution and toxicity. Harmful Algae 9: 190-199.

Sylaios G, Stamatis N, Kallianiotis A, Vidoris P (2005) Monitoring water quality and assessment of land-based nutrient loadings and cycling in Kavala Gulf. Water Resour Manag 19: 713-735.

Sylaios G, Theocharis V (2002) Hydrology and nutrient enrichment at two coastal lagoon systems in northern Greece. Water Resour Manag 16: 171-196.

Theoharatos G, Tselepidaki I (1990) The temperature of the sea surface in the region of the Aegean and its relation to air temperature. Theor Appl Climatol 42: 117-119.

Thomas WH, Glbson CH (1990) Effects of small-scale turbulence on microalgae. J Appl Phycol 2: 71-77.

Tillmann U, Elbrächter M, Krock B, John U, Cembella A (2009) Azadinium spinosum gen. et sp. nov. (Dinophyceae) identified as a primary producer of azaspiracid toxins. Eur J Phycol 44: 63-79.

Tilstone GH, Miguez BM, Figueiras FG, Fermín EG (2000) Diatom dynamics in a coastal ecosystem affected by upwelling: coupling between species succession, circulation and biogeochemical processes. Mar Ecol Prog Ser 205: 23-41.

U.S. Environmental Protection Agency (2000) Chapter 6: Meteorological data processing. In: Meteorological Monitoring Guidance for Regulatory Modeling Applications. U.S. Environmental Protection Agency, Office of Air and Radiation, Office of Air Quality Planning and Standards, February 2000.
Utermöhl H (1958) Zur Vervollkommnung der quantitativen Phytoplankton-Methodik. Limnol 9: 1-38.

Vale P (2012) Two simple models for accounting mussel contamination with diarrhoetic shellfish poisoning toxins at Aveiro lagoon: Control by rainfall and atmospheric forcing. Est Coast Shelf Sci 98: 94-100.

Vale P, Sampayo MAM (2003) Seasonality of diarrhetic shellfish poisoning at a coastal lagoon in Portugal: rainfall patterns and folk wisdom. Toxicon 41: 187-197.

Van den Hoek C, Mann DG, Jahns HM (1995) Algae: An introduction to phycology. Cambridge University Press, UK, 627 pp.

Vareli K, Zarali E, Zacharioudakis GSA, Vagenas G, Varelis V, Pilidis G, Briasoulis E, Sainis I (2012) Microcystin producing cyanobacterial communities in Amvrakikos Gulf (Mediterranean Sea, NW Greece) and toxin accumulation in mussels (Mytilus galloprovincialis). Harmful Algae 15: 109-118.

Velo-Suarez L, González-Gil S, Gentien P, Lunven M, Bechemin C, Fernand L, Raine R, Reguera B (2008) Thin layers of Pseudo-nitzschia spp. and the fate of Dinophysis acuminata during an upwelling-downwelling cycle in a Galician Ría. Limnol Oceanogr 53: 1816-1834.

Vlahakis GN, Pollatou RS (1993) Temporal variability and spatial distribution of sea surface temperatures in the Aegean Sea. Theor Appl Climatol 47: 15-23.

Vlamis A, Katikou P, Petridis D (2010) Management of the production and harvesting in Greek mussel culture areas, according to the occurrence of lipophilic toxic episodes. Int Aquat Res 2: 183-192.

White AW (1976) Growth inhibition caused by turbulence in the toxic marine dinoflagellate Gonyaulax excavate. J Fish Res Board Can 33: 2598-2602.

Yasumoto T, Oshima Y, Yamaguchi M (1978) Occurrence of a new type of shellfish poisoning in the Tohoku District. Bull Jpn Soc Sci Fish 44: 1249-1255.

Zingone A, Enevoldsen HO (2000) The diversity of harmful algal blooms: a challenge for science and management. Ocean Coast Manag 43: 725-748. 